\title{
Deficit irrigation strategies for subtropical mango farming. A review
}

\author{
Víctor Hugo Durán Zuazo ${ }^{1}$ (D) I Iván Francisco García-Tejero ${ }^{2} \cdot$ Belén Cárceles Rodríguez $^{1}$ - Dionisio Franco Tarifa ${ }^{3}$. \\ Baltasar Gálvez Ruiz ${ }^{1}$. Pedro Cermeño Sacristán ${ }^{2}$
}

Accepted: 13 January 2021 / Published online: 4 February 2021

(C) INRAE and Springer-Verlag France SAS, part of Springer Nature 2021

\begin{abstract}
Mango (Mangifera indica L.) is broadly grown in tropical regions and can also be cultivated in irrigated subtropical semi-arid areas; however, water shortages are a serious problem in the latter region. Among biotic and abiotic factors, water supply is one of the most crucial elements that determine productivity. The allocation of water will be an ever-increasing source of pressure because of vast agricultural demands under changing climatic conditions. Although the mango is considered to be tolerant to drought, water stress during growing cycle can reduce productivity. Here, we review the recent progress in evaluating and augmenting mango water productivity. Developments in physiological and agronomic understanding that have led to a boost in water productivity are presented. In addition, this review deals with deficit irrigation strategies to elucidate the effects on mango yield, water use efficiency, and the response of physiological indicators to water stress. Our main findings were as follows: (1) Under a changing climate, traditional irrigation based on water balance will not be sustainable in the medium/long term; (2) deficit irrigation strategies applied to mango can save irrigation water by up to $40 \%$ and improve water use efficiency by up to $30 \%$; and (3) there is valuable potential for further improvement owing to advanced knowledge in terms of the physiological response of mango to water stress, and there are good prospects within the current approaches if they are associated with specific environmental physiology. We concluded that under current medium-/long-term perspectives regarding available water resources, particularly in arid and semi-arid regions, there is an urgent demand for adaptive and water-saving strategies. Thus, it will be vital to redesign irrigation schemes in areas where water is scarce to adjust deficit irrigation strategies not only to save water, enhance water use efficiency, and maintain yield, but also to produce fruits with improved quality.
\end{abstract}

Keywords Andalucía · Deficit irrigation · Mangifera indica L. · Subtropical Mediterranean farming · Water stress · Water use efficiency

Contents

1. Introduction

2. Mango trees and their irrigation

2.1 Water requirements

2.2 Mango productivity

2.3 Water stress effects on mango growth and development

Víctor Hugo Durán Zuazo

victorh.duran@juntadeandalucia.es

1 IFAPA Centro "Camino de Purchil", Camino de Purchil s/n, 18004 Granada, Spain

2 Centro IFAPA “Las Torres”, Ctra. Sevilla-Cazalla km 12.2. 41200. Alcalá del Río, Seville, Spain

3 Finca "El Zahori”, Excmo. Ayto. de Almuñécar, Plaza de la Constitución 1, 18690 Almuñécar, Granada, Spain

\subsubsection{Flowering}

2.3.2 Fruiting

2.4 Impact of water stress on fruit quality

3. Improving water use efficiency

3.1 Deficit irrigation strategies

3.2 Plant physiological indicators in relation to water stress

4. Towards sustainable subtropical mango cultivation- - a Spanish case study

5. Conclusions and future perspectives

Authors' contribution

Funding

Compliance with ethical standards

References 


\section{Introduction}

The mango tree (Mangifera indica L.), dating back to 4000 $\mathrm{BC}$, originated in the foothills of the Himalayas of southern Asia bordering the Bay of Bengal (Crane 2008), where it still grows wild in the hills of Assam (Dinesh et al. 2015). The varieties that evolved in tropical regions have seeds with several genetically identical embryos, i.e. they are poly-embryonic. Conversely, mangoes that developed in subtropical areas of the Indian subcontinent are mono-embryonic (Mukherjee and Litz 2009). Thus, India is the centre of domestication for mono-embryonic cultivars and South-east Asia for poly-embryonic cultivars (Crane et al. 1997).

Nowadays, mango is cultivated from the tropics and subtropics up to northern latitudes of $35-37^{\circ}$ in the south of Spain and can be grown up to 1400 m a.s.l. (Galán 2009; Galán and $\mathrm{Lu} 2018$ ). The optimum growth temperature is $24-27^{\circ} \mathrm{C}$, and it is not tolerant to cold, sustaining damage below $0{ }^{\circ} \mathrm{C}$. Mango is the fifth most cultivated fruit in the world (Normand et al. 2015); it is widely consumed in both fresh and processed form and appreciated for its healthy bioactive compounds such as polyphenols, carotenoids, enzymes, vitamins $\mathrm{E}$ and $\mathrm{C}$, fibre, cellulose, hemicellulose, lipids, protein, enzymes, pectin, and fats (Jahurul et al. 2015).

The total world mango production is more than 40 million tonnes, but only a small part (3\%) is traded (Galán 2015; Mitra 2016). The main mango producing country is India $(2,237,000 \mathrm{ha})$, followed by China $(586,027 \mathrm{ha})$, Thailand (410,694 ha), and Mexico (206,423 ha). In terms of trade, the most important country is Mexico, representing $20 \%$ of the total world trade. Other important exporting countries include Thailand (11\%), Brazil (9\%), Peru (9\%), and Pakistan (7\%). The USA and Europe are the main markets for imported mangoes. The European Union is supplied mainly by imports from traditional mango producing countries such as Brazil (20\%, 137,500 tonnes) and Peru (18\%, 124,400 tonnes), and, on a smaller scale, Spain (7\%) (OPM 2020).

In the European Mediterranean basin, specifically in Spain, according to ESYRCE (2018), the area devoted to subtropical crops is approximately $4.3 \%$ of the total area of fruit trees and represents $2.2 \%$ of the total fruit production. In 2018, there were 4276 ha of irrigated mangoes, of which 3994 ha were on the coast of Malaga and Granada (SE Spain), in a narrow strip $12 \mathrm{~km}$ wide situated parallel to the littoral zone. The subtropical agriculture in this area is of great importance to economic development, since the direct and indirect benefits are considerable.

The mango cultivars most used in the European Mediterranean zone are cultivars from Florida such as Osteen, Keitt, Tommy Atkins, Irwin, and Sensation (Durán et al. 2003, 2006; Testa et al. 2018; Gentile et al. 2019).

While mango is grown mostly in tropical climates, there are remarkable advantages to cultivating it in the subtropics, where cooler winter temperatures enhance flower induction and both early bearing in younger trees and lower annual growth rates support high-density planting options. This is because mono-embryonic mango trees have fewer flushes per year, which eases the implementation of high-density plantations. Consequently, it is not surprising that the highest mango yields per hectare are found in subtropical regions.

The expansion and intensification of land use for agriculture have promoted an increase in water demand, especially in the Mediterranean area (Durán et al. 2013; García-Tejero and Durán 2018), but also in other regions (Fukuda et al. 2013; Ali et al. 2017; Ramos and Melo Júnior 2019). Water scarcity is a serious problem and will be worsened by climate change, which lead to increased potential evapotranspiration, decreased total rainfall, and increase the frequency of droughts (Chartzoulakis and Bertaki 2015). Today, in a period of substantial changes and water resource uncertainty, water distribution among economic sectors takes on a singular importance, as agriculture is the most important consumer of water resources (Iglesias and Garrote 2015; Normand et al. 2015).

Now more than ever, arid and semi-arid regions suffer from water shortages for agricultural use. In this sense, water shortage is one of the most important environmental impacts on woody fruit crops, limiting productivity and consequently economic development. Although mango has relatively good tolerance to drought, marketable fruits can only be achieved by irrigation (Spreer et al. 2013). However, water stress decreases vegetative growth and root development (Tahir et al. 2003; Shah et al. 2018), fruit drop is augmented during early season deficit irrigation periods (Schaffer et al. 1994), and fruit size decreases (Azzouz and El-Nokrashyand 1977) or is unaffected by water stress (Léchaudel et al. 2005) and fruit quality can even improve (Nora et al. 2012). By contrast, in the tropics, water stress plays an important role in regulating flowering and fruiting, as it provides the floral induction signal.

Efforts must be made to develop efficient water management systems in mango cultivation and subsequent irrigation scheduling under the climate change scenario, as it has already brought widespread changes to flowering and fruiting patterns. In this context, Galindo et al. (2018) studied the response of woody fruit crops to deficit irrigation, with attention to the impact on yield and fruit quality, and health-related chemical compounds were also analysed to assess the method's suitability for saving water in Mediterranean semiarid environments.

In this review, we analyse and describe advances in deficit irrigation strategies for mango, focusing on water use efficiency, yield, fruit quality, and plant physiological parameters to assess the water status under water stress conditions, particularly in semi-arid subtropical environments. 


\section{Mango trees and their irrigation}

\subsection{Water requirements}

Irrigation is not sustainable if the water supply is not adequate, especially in arid and semi-arid areas where the major demand in the development of irrigation is to optimise water use. It is essential to find application strategies that reduce water loss by soil evaporation and percolation beyond the depth of the root zone, and to reduce water loss from storage and delivery systems. To determine the water requirements, an ordinary procedure is to estimate reference crop evapotranspiration $\left(\mathrm{ET}_{0}\right)$, either from an evaporation pan or by the PenmanMonteith equation, after that calculate crop evapotranspiration $\left(\mathrm{ET}_{\mathrm{C}}\right)$ with the suitable crop coefficient $\left(\mathrm{K}_{\mathrm{C}}\right)$. However, the water requirements of mango trees depend on many factors, such as the orchard age and the phenological period. This has not been studied in depth, and there are few studies on subtropical areas related to water for mango cultivation.

Research findings based on the soil-water balance showed that water consumption for the reproductive period ranged from 3.0 up to $4.1 \mathrm{~mm}$ day $^{-1}$ depending on the irrigation level (Campos et al. 2008), and from 4.1 to $4.6 \mathrm{~mm} \mathrm{day}^{-1}$ in another study (Da Silva et al. 2001). In this context, in a semi-arid region, De Azevedo et al. (2003) obtained accumulated mango orchard water consumption of 551.6 and $55.1 \mathrm{~mm}$ by the soilwater balance and Bowen ratio-energy balance methods, respectively. It was determined that daily mango orchard evapotranspiration increased in the middle of July from 3.1 to $4.9 \mathrm{~mm} \mathrm{day}^{-1}$ at the maximum growth period of the fruit, and after that it lowered to $4.1 \mathrm{~mm} \mathrm{day}^{-1}$ at around the full fruit maturation stage. These authors reported the water requirements by $\mathrm{K}_{\mathrm{C}}$ obtained as a function of days after flowering (DAF) with the following equation: $\mathrm{K}_{\mathrm{C}}=0.36+0.009$ (DAF) $-4 \times 10^{-5}(\mathrm{DAF})^{2}$. Da Silva et al. (2007), using the Bowen ratio-energy balance during two monitoring seasons, reported that latent heat flux density $(\lambda \mathrm{E})$ could be estimated as a function of net radiation flux density ( $\mathrm{Rn}$ ), and the percentage of $\mathrm{Rn}$ used as $\lambda \mathrm{E}$ was higher during the fruit growth and maturation stages and lower during the flowering and fruit fall stages. They highlighted that $\lambda \mathrm{E}$ was the major component of the energy balance, comprising $>70 \%$ of the available energy, while the soil heat flux was a smaller component, at $<8 \%$. Similarly, Teixeira et al. (2008), using the eddy covariance technique throughout two monitoring seasons, estimated an accumulated actual evapotranspiration of $1419 \mathrm{~mm}^{-1} \mathrm{ear}^{-1}$, corresponding to a daily average of $3.7 \mathrm{~mm} \mathrm{day}^{-1}$. The $20 \%$ of evapotranspiration originating from soil evaporation and the average relative water supply amounted to $1.1 \mathrm{~mm}$. Thus, the resulting evapotranspiration deficit was between 73 and $95 \mathrm{~mm}$ per season.

In a study by Mohammad et al. (2015), the measured evapotranspiration rate for mature mango averaged $5.9 \mathrm{~mm} \mathrm{day}^{-1}$, and the daily rate of water use for drip and surface irrigation averaged 0.114 and $0.172 \mathrm{~m}^{3}$ tree $^{-1}$ day $^{-1}$, respectively. Therefore, the total average annual water use was $31.63 \mathrm{~m}^{3}$ tree $^{-1}$ season $^{-1}$. De Souza et al. (2016) estimated evapotranspiration rates during the mango reproductive period ranging from 402 to $420 \mathrm{~mm}$, with mean daily water consumption at flowering, fruit fall, fruit formation, fruit maturation, and over the entire period of $3.8,4.25,3.56,3.0$, and $3.73 \mathrm{~mm}$, respectively. Da Silva et al. (2009) reported the accumulated evapotranspiration during two seasons ranging between $371.4\left(70 \% \mathrm{ET}_{0}\right)$ and $482.8 \mathrm{~mm}\left(100 \% \mathrm{ET}_{0}\right)$.

The findings from studies regarding water requirements suggest that mango is a moderately demanding crop and suitable for cultivation under deficit irrigation, especially in subtropical areas. This contrasts with other subtropical trees, such as avocado (Persea americana Mill.), that are much more demanding and need large amounts of water. In addition, the comparison of the amount of water consumed by mango trees over the growing cycle from the various producing areas revealed differences, mainly due to variations in climatological conditions, soil type, and cultivar type. In general, the amount of water needed for mango is found to increase from the initial stage to mid-season and reduces at the end of the late season. The maximum amount of water is required at the flowering and fruit-setting stage and comparatively less water is required during the initial and fruit maturity stages. Undoubtedly, evapotranspiration is the essential and dominant factor in mango water requirement estimation.

Studies related to crop water requirements are often based on $\mathrm{ET}_{0}$ and $\mathrm{K}_{\mathrm{C}}$ tabulated by $\mathrm{FAO}$, which for mango is 0.8 (Allen et al. 1998). Other authors indicated a $K_{C}$ value for mango trees of 0.75 (Da Silva et al. 2009), between 0.71 and 0.77 (Mohammad et al. 2015), from 0.65 to 1.05 (Carr 2014), 0.8 (Spreer et al. 2007), and a progressive $K_{C}$ from 0.4 (flowering) to 0.8 (fruit growth) (De Azevedo et al. 2003). The mango $\mathrm{K}_{\mathrm{C}}$ estimated by using drainage lysimeters in a semiarid subtropical Mediterranean environment for flowering, fruit set, and fruit growth stages averaged 0.43, 0.67, and 0.63, respectively (Fig. 1a) (Durán et al. 2019). According to Levin et al. (2018), the fruit yield for the main fruit growth stage did not respond to $\mathrm{K}_{\mathrm{C}}$ higher than 0.38 ; however, a $\mathrm{K}_{\mathrm{C}}$ of 0.63 should be considered in Mediterranean semi-arid zones to avoid decreased fruit yields. Finally, Teixeira et al. (2008) measured $K_{C}$ values based on evapotranspiration and transpiration of 0.91 and 0.73 , respectively. In this context, this approach is appropriate for woody crops, since water use and requirements depend on several factors such as the local microclimate, soil conditions, and phenological phase, which permit the calculation of $\mathrm{K}_{\mathrm{C}}$ for the different stages of development. However, Spreer et al. (2009a) claimed that the mango $\mathrm{K}_{\mathrm{C}}$, which is commonly used to calculate potential $\mathrm{ET}_{\mathrm{C}}$ based on $\mathrm{ET}_{0}$, overestimates its water requirements.

Today, climate change is provoking increased demand for water, due to both the rise in temperature and oscillation in 

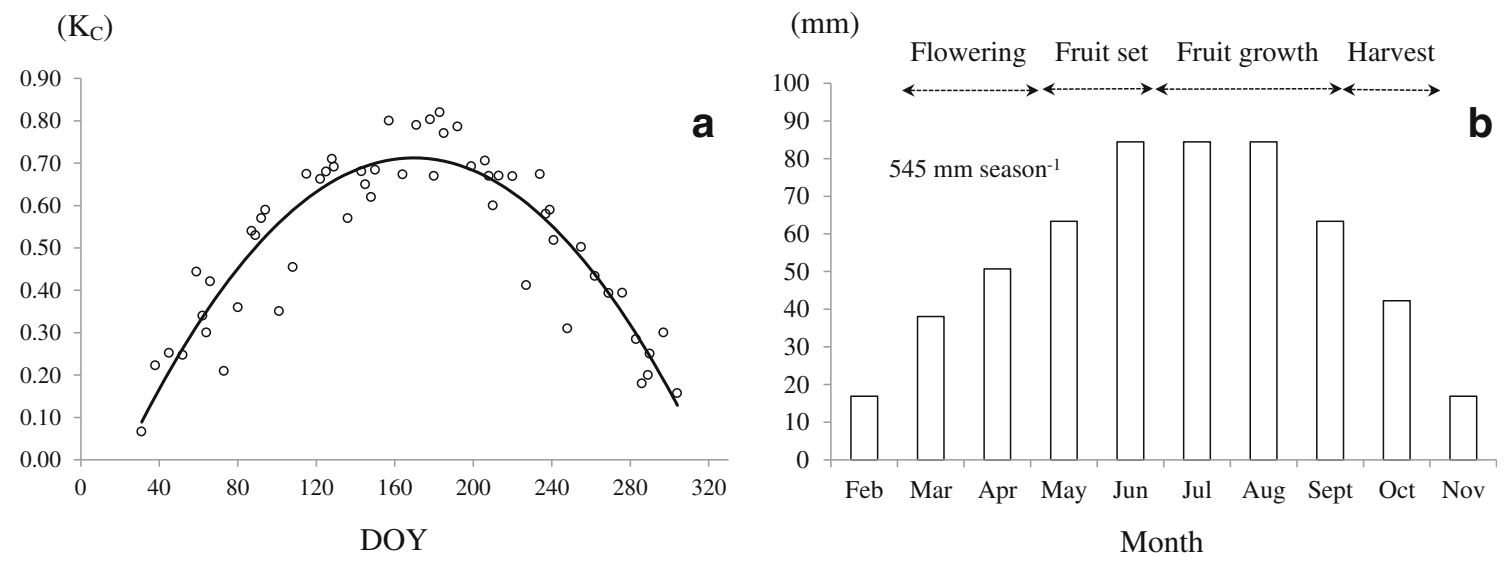

Fig. 1 Estimated crop coefficient $\left(\mathrm{K}_{\mathrm{C}}\right)$ for mango tree (a) and monthly irrigation doses (b) throughout the growing cycle for terraced plantation in subtropical Mediterranean environment (SE, Spain). DOY, day of the year

rainfall patterns. Since water requirements are associated with the climate and irrigation scheduling depends on $\mathrm{ET}_{\mathrm{C}}$, it is vital to have tools that allow the estimation of $\mathrm{ET}_{\mathrm{C}}$ in a realistic manner. In this sense, the use of weighting or drainage lysimeters could be useful tools for estimating $\mathrm{K}_{\mathrm{C}}$. In this section, the presented $\mathrm{K}_{\mathrm{C}}$ values were measured in different mango-producing countries with different weather conditions. Thus, we believe that it could be more efficient to consider the specific environmental conditions for a given producing area with the aim to offer a practical tool for selecting the most appropriate $\mathrm{K}_{\mathrm{C}}$ for water balance irrigation scheduling. In addition, improved water use at the canopy level can be attained by adopting practices that reduce the soil-water evaporation component and divert more water to transpiration, which can be achieved by dwarfing canopy cultivars, crop residue management, mulching, row spacing, and irrigation. Climate change will certainly affect plant growth; therefore, enhancing water use through crop selection and cultural practices is essential to offset the effects.

With regard to the amount of water irrigation used per season, Mostert and Hoffman (1997) reported that the water requirement for a mango plantation in South Africa under optimal conditions amounted to $11,976 \mathrm{~m}^{3} \mathrm{ha}^{-1}$ year $^{-1}$. For the semi-arid zone of Israel, Levin et al. (2018) reported seasonal irrigation of $11,980 \mathrm{~m}^{3} \mathrm{ha}^{-1}$ year $^{-1}$ for mango cv. Keitt. Mohammad et al. (2015) highlighted water requirements for drip and surface irrigation of 6527 and $9790 \mathrm{~m}^{3} \mathrm{ha}^{-1}$ year ${ }^{-1}$, respectively, in Saudi Arabia. In SE Spain, to cover the full water requirements of mango based on $\mathrm{ET}_{\mathrm{C}}$, irrigation ranges between 4740 and $5451 \mathrm{~m}^{3} \mathrm{ha}^{-1}$ year $^{-1}$, which is highly variable and depends on the season (Durán et al. 2011, 2021). In this context, Fig. 1b shows irrigation water applied on a monthly basis on a reverse-slope bench-terrace with single rows of mango trees spaced $3 \mathrm{~m}$ apart. Under these experimental conditions, a cultivated hectare of mango trees on steeply sloped land would have 18 terraces $100 \mathrm{~m}$ long, spaced about $5 \mathrm{~m}$ apart, with an average of 660 trees per ha.
Thus, the water irrigation amounts depend on the growing environment, the level of the water deficit applied, the stage of growth, and age of plantations. Because of these complexities, water productivity has to be quantified across a range of environments.

\subsection{Mango productivity}

In many mango-producing countries, a high-density planting system emerged on plantations to boost the fruit production level. In India, Adak et al. (2019) reported that with 400, 267, and 100 trees $^{-1} \mathrm{~h}^{-1}$, the fruit yield amounted to 16.0, 10.0, and 5.5 tonnes $\mathrm{ha}^{-1}$, respectively. In Brazil, Cotrim et al. (2011) reported a fruit yield of 25.4 tonnes $\mathrm{ha}^{-1}$ from a mango plantation with a spacing of $8 \times 8 \mathrm{~m}$ (around 155 trees $\mathrm{ha}^{-1}$ ). Similarly, in the Brazilian subtropical zone, the yield of mango cv. Keitt reached 18.2 tonnes ha $^{-1}\left(417\right.$ trees ha $^{-1}$ ) (Souza et al. 2018). In Ghana, Nettey et al. (2017) reported 8.0 and 10.7 tonnes ha ${ }^{-1}$ for rainfed and irrigated mango (100\% crop water requirement) plantations, respectively. The average mango yield for traditional producing areas in China amounted to 16.9 tonnes ha ${ }^{-1}$ (Dong et al. 2019), which no varies considerably with than those reported in 2017 for the USA (15.4 tonnes ha ${ }^{-1}$ ) and South Africa (18.4 tonnes ha ${ }^{-1}$ ). In the Mediterranean subtropical area, Durán et al. (2011, 2021) reported that terraced plantations of mango cv. Osteen yielded between 14.5 and 25.3 tonnes $\mathrm{ha}^{-1}$.

The fruit yield per tree in the Mediterranean subtropical area differs appreciably from that of fully tropical climates, where both tree size and yield are greater. This is because the climatic conditions of the subtropical region represent the marginal limit for mango to develop normally; therefore, tree size and yield are lower. However, these conditions enable orchards to have dense planting grids and improved light interception and distribution, in contrast with low planting density, which leads to increased difficulty with spraying and harvesting, and lower mango 
yield as a result. Thus, high-density plantings have more potential for improved yields and returns than conventional plantings (tropics), particularly during the early years of mango plantation. However, in many other mango-producing areas, many efforts to control the growth through the use of dwarfing material, canopy management, and growth regulators are required. In this context, water stress could be an important effect because it regulates tree growth; this was identified in experiments by assessing the relationship between yield and tree growth (Durán et al. 2011). Thus, the future of high-density plantings will be dependent on plant breeding and the development of canopy management strategies, which has a significant impact on mango productivity (Menzel and Le Lagadec 2017).

\subsection{Water stress effects on mango growth and development}

Based on the BBCH (Biologische Bundesantalt, Bundessortenamt, und Chemische Industrie) scale, Hernández et al. (2011) stated that mango uses 7 of the 10 principal phenological stages: growth stages for bud, leaf, and shoot development; inflorescence emergence; flowering; fruit development; and fruit maturity. Shoot growth takes place in periodic flushes which can last from three to 6 weeks, after which there is a period of dormancy during which soil-water availability is essential. However, the number of periods of vegetative growth depends on the climatic conditions and mango variety. According to Tahir et al. (2003), water stress provokes important depletion in the emergence of new vegetative flushes during the imposed stress period. Furthermore, the number of leaves per flush, flush length and weight, leafwater content, and root growth is also reduced due to water stress.

Luvaha et al. (2008) with pots experiment found that growth parameters increased under mild water stress except under extreme conditions where there was wilting, and the root-to-shoot ratio increased with increasing water stress. According to Levin et al. (2018), varying the water stress by irrigation levels during the post-harvest period had a significant effect on autumnal vegetative growth in the following season, particularly in increasing the number of new vegetative shoots. Therefore, increased production of new autumn vegetative shoots may influence the yield in the following season, particularly in terms of fruit weight rather than number.

\subsubsection{Flowering}

A period of water stress is beneficial for inducing flowering in the tropics but is of minimal importance in the subtropics, where low winter temperatures restrict growth and induce flowering. Moreover, leaf carbohydrate accumulation in the subtropics could be negatively affected by severe water stress. A mature mango tree can potentially produce $200-4000$ flowers mainly on terminal panicles. In the same inflorescence, hermaphrodite and male flowers can be found. The factors that promote flowering in mango are twofold, depending on the latitudinal position. In the tropics, flowering takes place after 6-12 weeks of water stress, while in the subtropics and semi-arid areas, irrigation is crucial for the development of the following phenological stages that culminates with fruit production under conditions of high temperatures (Davenport 2003; Carr 2014). According to Bally et al. (2000), water stress management could be utilised to induce flowering in mango trees, as water stress significantly increased the number of terminals that flowered by $20.5 \%$ and yields were increased by $17 \%$ by withholding irrigation in two of three studied seasons. Similarly, it was revealed that a water deficit at pre-flowering might enhance flowering intensity; however, it has a detrimental effect during the flowering, pollination, and fruit set stages (Núñez and Davenport 1994; González et al. 2004). Madigu et al. (2009) determined that water stress by suppressed irrigation 40 days after flowering gave firmer fruit with longer shelf life than fruit from trees irrigated throughout the season.

Therefore, the benefits of water stress that do not compromise mango physiology include improved floral induction capacity and adequate fruit yield, particularly in tropical regions. Similarly for subtropical areas, the water stress can be used to control the pattern of shoot growth.

\subsubsection{Fruiting}

In relation to the fruit set and maturity stages, water stress should be avoided during the first four to 6 weeks after anthesis, since cell walls are synthetised during this period (Schaffer et al. 1994). Only approximately $1 \%$ of fruits reach maturity (Davenport 2009), and this takes 3-4 months. Comparably, Larson et al. (1989) and Spreer et al. (2007) outlined that mango fruit drop at an early developmental stage is associated with water stress, which can be prevented during flowering and the first 6 weeks after fruit set.

Léchaudel and Joas (2007) found that water stress during the critical phenological stages of the reproductive cycle (flowering, fruit growth, and maturation) significantly affected fruit retention and size, as water stress is an important determining factor in regulating flowering and fruiting. In addition, Azzouz and El-Nokrashyand (1977) revealed that mango fruit number and size increased with reduced water stress provoked by withholding irrigation. Roughly, $80 \%$ of the final mango size was achieved in the fruit growth stage, characterised by rapid, expansive fruit growth that was associated mainly with a high rate of cell division and expansion (Tharanathan et al. 2006). In a study by Diczbalis et al. (1993), 
the impact of water stress before harvest reduced fruit weight by $45 \mathrm{~g}$. Similarly, Kuppelwiesser (1990) claimed a decline of fruit weight from 52 to $69 \mathrm{~g}$ in trees that were water-stressed 5 weeks before harvest. Durán et al. (2011) stated an averageweight fruit reduction due to water stress of from 648.4 to $536.9 \mathrm{~g}$ for non-stressed $\left(100 \% \mathrm{ET}_{\mathrm{C}}\right)$ and severely waterstressed $\left(33 \% \mathrm{ET}_{\mathrm{C}}\right)$ trees, respectively.

The effect of irrigation on the number of fruits may be due to favourable conditions in the fruit set stage or a reduction in fruit fall. Pavel and Villiers (2004) revealed that differences in fruit yield seemed to be mainly related to fruit number, indicating that water stress might have affected growing conditions before flowering or during the early stages of fruit growth rather than later in the season. However, the factors affecting fruit size are diverse, as indicated by Schaffer et al. (2009), primarily in the genetic components of the cultivar, but also in other important factors including fruit load, vegetative growth, and carbon/nitrogen ratio. On the other hand, Simmons et al. (1998) reported a trend of increasing fruit size with number of leaves per fruit in response to water stress, and Léchaudel et al. (2005) found that the leaf-to-fruit ratio markedly increased the fresh weight of mango.

According to Bally (2006), mango exhibits some adaptive features that give it drought tolerance, such as deep tap/sinker roots, long-lived tough leaves with thick cuticles, and resin ducts to reduce wilting. These adaptation mechanisms increase its ability to survive under water stress conditions. Dos Santos et al. (2014a) revealed that water stress during fruit set does not influence either root distribution or production, and root system development and mango productivity are significantly lessened by water stress provoked by the absence of irrigation.

We conclude that the impact of water stress is relevant at the flowering stage depending on the environmental characteristics of the region considered (subtropical or tropical). In general, water stress delays the development of vegetative buds but stimulates the growth of floral buds. Water stress has an injurious effect during fruit set and fruit growth stages when fruiting demand for photoassimilates is elevated. It is evident from the reviewed literature that imposing water stress affects mango development; however, due its congenital response to water-stress, mango has great potential for adaptation to an adverse environment. Therefore, intensive research is required to elucidate the effect of water stress on mango by seeking the most sensitive stage of the plant's life to water stress, which will be essential for its proper management under environmental constraints.

\subsection{Impact of water stress on fruit quality}

According to Ahmad et al. (2018), variability in mango fruit quality with respect to flavour, colour, aroma, weight, size, and shape is highly influenced by the field practices applied during the production process. In general, water stress can enhance the fruit quality of many fruit crops by increasing dry matter percentage and sugar concentration, among other parameters, although in this context studies on mango are scarce (Spreer et al. 2007; Nora et al. 2012). In this line, Léchaudel et al. (2005) highlighted that with mild water stress, fructose levels were higher in the fruit where irrigation was ceased 30 days after flowering. Durán et al. (2021) reported higher Brix (total soluble solid), vitamin $C$, and $\beta$-carotenoid values in mango cv. Osteen fruits from water-stressed trees compared to non-water-stressed trees. Wei et al. (2017) highlighted the same effect of water stress on fruit quality parameters of mango cv. Guifei. According to Madigu et al. (2009), the $\beta$-carotene content increased, with a gradual reduction in anthocyanin when approaching fruit maturity and the fruits from non-irrigated trees (water-stressed) had higher anthocyanin content than fruits from irrigated trees (non-water-stressed). Similarly, Rosalie et al. (2015) highlighted the impact of water stress on mango fruit quality parameters by reducing water supply. In line with this, Abdel-Razik (2012) claimed improvements in the quality and storability of mango fruit due to deficit irrigation strategies applied during the production process. That is, deficit irrigation could be applied successfully to mango trees to balance the vegetative and reproductive growth with acceptable yield and improved fruit quality. In addition, improved knowledge of the causal mechanisms involved in the positive and negative effects of water stress on aspects of mango fruit quality would assist in identifying which irrigation practices can be used to augment fruit quality.

In this context, the relationship between water stress and many fruit crops is beneficial. Wang et al. (2019) reported improvements in fruit quality of apple (Malus domestica Borkh.) due to water stress. Moreover improvements were reported by Mossad et al. (2020) for oranges (Citrus sinensis L.), Romero et al. (2016) for grapes (Vitis vinifera L.), Gonçalves et al. (2020) for olives (Olea europea L.), Pérez et al. (2016) for apricots (Prunus armeniaca L), Maatallah et al. (2015) for plums (Prunus salicina L.), and Cano et al. (2018) for pomegranates (Punica granatum L.).

In short, water scarcity makes it crucial to understand water stress management for more competitive crop irrigation systems. Despite mango being a crop tolerant to water stress, irrigation is necessary to ensure fruit production since cell enlargement and division require water. Particularly, fruit development in subtropical semi-arid areas takes place during the dry period, and farmers must irrigate to enhance yields and obtain good-quality fruits. Thus, improving our understanding of the interactions among yield, fruit quality, and water use efficiency from agronomic and environmental perspectives should be considered a high priority. 


\section{Improving water use efficiency}

Water use efficiency (WUE) is considered a measure of a plant's efficiency in using water, and is a ratio between two physiological processes (transpiration and photosynthesis or carbon assimilation) or agronomic parameters (yield and crop water use). In this context, in semi-arid subtropical regions, there are not enough water resources to meet the demand; thus, there is increased competition among potential users (Fernández et al. 2009; Buytaert et al. 2012).

Most of the mango growing regions in the world are found in tropical areas, where there is less need for irrigation and/or it is mainly supportive and specific for the dry season, in contrast to subtropical regions, where irrigation and water stress management are crucial (Williamson and Crane 2010; Carr 2014). Studies on subtropical environments in relation to mango irrigation requirements are still scarce; early experiments were focused on developing deficit irrigation strategies for the entire fruiting period, as reported by Pavel and Villiers (2004).

Deficit irrigation can stabilise yields and maximise water productivity while maintaining or increasing profits, especially under water shortage conditions, can improve WUE because water is allocated properly (García-Tejero and Durán 2018). It is particularly suitable for crops in which flowering and fruit development stages take place during the dry season. According to Kirda et al. (1999), the principle of deficit irrigation is to enhance WUE by reducing irrigation from the full requirement of one or more phenological stages with the smallest impact on crop growth and yield. Spreer et al. (2009a) reported that a deficit irrigation design could save considerable amounts of water without affecting the yield to a large extent, possibly increasing the average mango fruit weight, and apparently without having any negative long-term effects. Bithell et al. (2010) reported high WUE values (132 and $174 \mathrm{~kg} \mathrm{~m}^{-3}$ ) for mango yields of 62 and $122 \mathrm{~kg}^{-1} \mathrm{tree}^{-1}$ with irrigation inputs of 0.47 and $0.70 \mathrm{~m}^{3}$ tree ${ }^{-1}$, respectively, in Australia. In Spain, the WUE was improved by reducing the irrigation amount by $50 \%$ based on $\mathrm{ET}_{\mathrm{C}}$, with $7.1 \mathrm{~kg} \mathrm{~m}^{-3}$ compared with $3.1 \mathrm{~kg} \mathrm{~m}^{-3}$ for fully irrigated control trees with $100 \% \mathrm{ET}_{\mathrm{C}}$ (Durán et al. 2011). Comparable findings for mango were found in irrigation trials by Pavel and Villiers (2004) in South Africa and Spreer et al. (2009a) in Thailand. Consequently, increasing the water supply to mango does not result in higher yields or WUE, as has also been pointed out by Campos et al. (2008) in Brazil.

For a deficit irrigation practice to successfully boost WUE, it is important to define the threshold water deficit levels that will not have a deleterious impact on plant growth and fruit yield. The response to water stress and adaptation mechanisms need to be deeply understood to implement deficit irrigation. Knowing the effects of water restriction imposed throughout the phenological stages, in particular in those periods of highest plant sensitivity to water deficit, is essential for management of the water-stressed trees and to maximise the WUE.

\subsection{Deficit irrigation strategies}

Deficit irrigation is a management practice that is becoming popular to conserve water and sustain crop production in water deficit production areas. The main techniques are sustained-deficit irrigation (SDI) and regulated-deficit irrigation (RDI). SDI is a method that supplies the same ratio of $\mathrm{ET}_{\mathrm{C}}$ throughout phenological development, which implies increasing the water stress over the growing season (Fereres and Soriano 2007). RDI involves causing stricter water stress during certain phenological stages. This is basically done because the plant reacts in a different way to water stress according to the phenological phase, and this facilitates the management of vegetative growth, fruit size, and yield.

Another type of deficit irrigation is partial root drying (PRD), which has been used in many fruit crops (Jovanovic and Stikic 2018). This is based on exposing one part of the root system to dry conditions and keeping the other part well watered. The cycles of wetting-drying last from 7 to 15 days. As a result of these alternating periods, biochemical responses occur, leading to a balance between vegetative and reproductive growth (Sepaskhah and Ahmadi 2010). The stress in the root system evokes an abscisic acid (ABA) signal, which regulates stomatal opening and closing. Therefore, changes in the root growth or water supply of mango trees promote adaptations in the plant's anatomy, and in this way, roots can uptake nutrients in situations where there is a smaller volume available.

In this context, Zaharah and Razi (2009) showed that root restriction reduced leaf expansion and consequently the growth of mango trees, and there was even less leaf expansion under water deficit conditions. Consequently, water and root restriction can regulate tree size with physiological and morphological changes. Experiments showed that the PRD strategy can save irrigation water without affecting fruit quality and ripening (Spreer et al. 2007; Spreer et al. 2009a, b), while mango yield losses were smaller and water productivity was substantially increased (Spreer et al. 2009a). The yield was not affected by the water supply mode in either the full or half root zone but was a function of total available water, as defined by Spreer et al. (2009b).

In particular, Spreer et al. (2009a) conducted an experiment to evaluate the impact of different deficit irrigation techniques on mango cv. Chok Anan productivity, determining that these techniques can improve water productivity. The authors reported no yield differences between mature trees under deficit irrigation $\mathrm{DI}_{50}$ (50\% of full irrigation) and $\mathrm{PRD}_{50}(50 \%$ of full irrigation), and greater yield under $\mathrm{DI}_{75}$ (75\% of full irrigation) than $100 \%$ fully irrigated controls (non-significant difference). Differences in yield were mainly ascribed to the 
number of fruits per tree rather than a beneficial influence on fruit size development. Concretely, PRD increases fruit weight, and the number of unmarketable fruits per tree can be reduced, so this strategy could be recommendable in arid and semi-arid areas. Comparably, Spreer et al. (2007) reported that both PRD and RDI had better fruit size distribution than fully irrigated controls, with roughly $60 \%$ of the fruit over $250 \mathrm{~g}$, as a result of the interaction between fruit size and crop load (less fruit was harvested with PRD and RDI compared to control trees). Srikasetsarakul et al. (2011) examined the impact of $\mathrm{PRD}$ at $50 \% \mathrm{ET}_{\mathrm{C}}$ on proline content and yield, stating that there were no significant differences compared with fully irrigated trees; however, they found a strong correlation between leaf proline and average water content. Comparable, Zaharah and Razi (2009) revealed that root restriction and water stress contributed to increased leaf proline content and ABA levels, but these decreased with re-watering. The fruit growth rate, yield, and WUE were similar in both treatments, with more than $90 \%$ of fruit marketable. In Thailand, Satienperakul et al. (2009) found that PRD was a more practical strategy than the locally used system, as it has high economic potential to be implemented for exportable mango fruit production.

On the other hand, the RDI strategy proved to be more efficient with respect to fully irrigated trees, with water savings ranging from 32 to $58 \%$ without a significant reduction in the yield of mango cv. Kent (Pavel and Villiers 2004). Dos Santos et al. (2016) evaluated the effects of RDI and PRD on the yield of mango cv. Tommy Atkins in semi-arid conditions. Treatments were applied at the following phenological phases: I, early blooming to early fruit expansion; II, early expansion to early physiological ripening; and III, physiological ripening of fruits, with a combination of RDI of 100,75 , and $50 \%$ of $\mathrm{ET}_{\mathrm{C}}$ and PRD (15-day alternation) of 100, 80, 60, and $40 \%$ of $\mathrm{ET}_{\mathrm{C}}$. According to the findings, carboxylation and quantum efficiency of photosynthesis were lower in PRD at $40 \% \mathrm{ET}_{\mathrm{C}}$ compared with full irrigation and $\mathrm{PRD}$ at $80 \% \mathrm{ET}_{\mathrm{C}}$. Phase II was found the most appropriate for application of $\mathrm{RDI}$ at 50 and $75 \% \mathrm{ET}_{\mathrm{C}}$ without affecting yields and with higher WUE (PRD at $40 \% \mathrm{ET}_{\mathrm{C}}$ with the highest WUE). Table 1 presents the main studies related to RDI, PRD, and water-use efficiency in mango trees achieved over recent years.

With regard to the SDI strategy, in south-eastern Spain, Durán et al. (2011) evaluated the impact of three SDI strategies on mango fruit yield cv. Osteen throughout two monitoring seasons: $\mathrm{SDI}_{33}, \mathrm{SDI}_{50}$, and $\mathrm{SDI}_{75}$ received 33,50 and $75 \%$ of $\mathrm{ET}_{\mathrm{C}}$, respectively, compared with mature fully irrigated trees used as controls $\left(100 \% \mathrm{ET}_{\mathrm{C}}\right)$. They showed that $\mathrm{SDI}_{50}$ had the highest yield and WUE; thus, the greatest water volume did not result in the highest yield.

Schulze et al. (2013) carried out an experiment with mango cv. Nam Dokmai to test potential water savings and monetary income under different micro-sprinkler irrigation regimes (full irrigation (FI), deficit irrigation (DI), and farmer-controlled scheduling) compared with farmer-controlled scheduling with manual use of a water hose. The cost-benefit analysis showed that investing in a micro-sprinkler system can be recommended (up to $55 \%$ under FI), since the marketable yield of fruits increased (31\% in class I fruits larger $300 \mathrm{~g}$ ) and DI increased the crop water productivity and stabilised mango yields during drought periods. Table 2 presents the main studies related to SDI strategies and water use efficiency in mango trees.

As was shown, very little work has been published on the impact deficit irrigation of mango; these data, from short- to medium-term studies, confirm the significant variability in the impact of RDI, PRD, and SDI on mango productivity due to experimental conditions (i.e. climatic conditions, mango cultivars, age of trees, soil type). The main potential sources of variation could be due to an absence of harmony between methodological conditions and the objectives of each study. In this context, the effect of deficit irrigation in quite different environmental situations provides a better understand of the potential benefits and risks related with this irrigation strategy. In general, the studies proved the agronomic and environmental benefits of deficit irrigation on mango cultivation, especially those regarding water savings and fruit quality. However, it is crucial to establish the effects of water stress by means of deficit irrigation in long-term studies, and to assess the degree to which mango trees could be under-irrigated without reducing income below levels earned with trees under full irrigation. Thus, these findings confirm the potential that exists for improve the water productivity of mango by applying less irrigation water.

Lastly, water stress impacts can be managed using the most suitable plant genotypes in conjunction with adaptive agronomic practices (irrigation, plant density, and soil management). From our perspective, the mechanisms to accomplish this objective must involve producing suitable plant cultivars and improving the existing high-yield cultivars. In this sense, many efforts have been made to produce drought-tolerant genotypes for several fruit crops using the knowledge of plant responses to drought stress and the mechanisms involved.

\subsection{Plant physiological indicators in relation to water stress}

Research assessing the water status of crops is increasingly based on plant responses to imposed water stress. Today, many indicators can be used to evaluate this response. One of the most popular is the leaf-water potential $\left(\Psi_{\text {leaf }}\right)$, which was used in irrigation scheduling in woody fruit crops (Blanco et al. 2017, Dhillon et al. 2019). By contrast, the stem-water potential $\left(\Psi_{\text {stem }}\right)$ at midday is considered a good indicator of tree water status, but has not yet been used at all in commercial orchards. 
Table 1 Main regulated deficit irrigation (RDI) and partial root drying (PRD) studies in mango cultivation

\begin{tabular}{cc}
\hline Author & Aim of study \\
\hline $\begin{array}{c}\text { Pavel and } \\
\text { Villiers }\end{array}$ & $\begin{array}{c}\text { Fruit yield and physiological response to five irrigation regimes: } \\
\text { control, RDI, and two progressively reduced irrigation } \\
\text { (2004) }\end{array}$ \\
treatments $\left(\mathrm{PRI}_{1}\right.$ and $\left.\mathrm{PRI}_{2}\right)$, and a farm control
\end{tabular}

Spreer et al. Assessed effects of RDI and PRD on yield and quality (2004, (2007) 2005): control trees irrigated with $268.7 \mathrm{~mm}$ (2004) and $231.2 \mathrm{~mm}$ (2005), RDI and PRD received 137.5 and $131.2 \mathrm{~mm}$ (2004) and 150.0 and $125.0 \mathrm{~mm}$ (2005), respectively

Spreer et al. Evaluated fruit yield response to irrigation strategies: full irrigation (2009a)

Spreer et al. (2009b)

Cotrim et al. (2011)

Dos Santos et al. (2014a, 2014b)

Dos Santos et al. (2015)

Dos Santos et al. (2016)
Response of yield and WUE to four irrigation treatments: $100 \%$ $\mathrm{ET}_{\mathrm{C}}, 50 \% \mathrm{ET}_{\mathrm{C}} \mathrm{RDI}, 50 \% \mathrm{ET}_{\mathrm{C}} \mathrm{PRD}$ applied to alternating sides of the root system, and rainfed treatment as control

Assessed the response of productivity and fruit quality to water deficiency (based on \% $\mathrm{ET}_{\mathrm{C}}$ ) applied by RDI at different phases of fruit growth (I, II, and III) with 10 and 8 treatments for the first and second year

Evaluated the effects on yield, root system distribution, and photosynthesis rate by irrigation: $100 \% \mathrm{ET}_{\mathrm{C}}$ (phases I, II and III); RDI $50 \% \mathrm{ET}_{\mathrm{C}}$ (phase I, beginning of flowering to early fruit growth); RDI $50 \% \mathrm{ET}_{\mathrm{C}}$ (phase II, start of expansion to beginning of physiological maturity); RDI $50 \% \mathrm{ET}_{\mathrm{C}}$ (phase III, physiologically mature fruits); and no irrigation during all three phases

Evaluated yield, WUE, and physiological response under full irrigation and $\mathrm{PRD}$ with 15-day alternation: $100 \% \mathrm{ET}_{\mathrm{C}}$; $\mathrm{PRD}$ $100 \% \mathrm{ET}_{\mathrm{C}}$; PRD $80 \% \mathrm{ET}_{\mathrm{C}}$; $\mathrm{PRD} 60 \% \mathrm{ET}_{\mathrm{C}}$; and $\mathrm{PRD} 40 \% \mathrm{ET}_{\mathrm{C}}$

Evaluated the effects of RDI and PRD on yield, WUE, and gas exchange in phases: $\mathrm{P}_{\mathrm{I}}$, early blooming to early fruit expansion; $\mathrm{P}_{\mathrm{II}}$, early expansion to early physiologic ripening; and $\mathrm{P}_{\mathrm{III}}$, physiologic fruit ripening. With RDI at 100,75 , and $50 \% \mathrm{ET}_{\mathrm{C}}$ in
Main findings

Deficit irrigation strategies led to water saving of 32 to $58 \%$. Leaf photosynthetic rates were reduced in $\mathrm{PRI}_{2}$, and before flowering, $\mathrm{g}_{\mathrm{S}}$ was lower in RDI. The $\mathrm{PRI}_{1}, \mathrm{PRI}_{2}$, and RDI reduced vegetative growth with respect to control trees. Fruit yield was not affected by irrigation treatment; however, differences seemed to be mainly related to fruit number, indicating that reduced irrigation might affect growing conditions before flowering or at early stages of fruit growth rather than later in the season.

Yields were reduced in deficit irrigation treatments compared to fully irrigated control. However, development and post-harvest fruit quality grown under deficit irrigation were not adversely affected. Under PRD, fruit size was increased, and fruits had a higher fraction of edible parts compared to other treatments. Thus, in areas where water is a limiting factor for production, PRD may be a sustainable tool for increasing mango productivity.

The results showed a potential to increase WUE by deficit irrigation strategies. Only in 1-year yield in PRD trees was significantly lower than in FI. During the second year, there was no significant difference between $\mathrm{DI}_{50}$ and PRD. Finally, the $\mathrm{DI}_{75}$ had the greatest yield but not significantly higher than FI.

Average yield was $83.35 \mathrm{~kg}^{-1} \mathrm{tree}^{-1}\left(100 \% \mathrm{ET}_{\mathrm{C}}\right), 80.16 \mathrm{~kg}^{-1} \mathrm{tre}^{-1}$ (50\% $\left.\mathrm{ET}_{\mathrm{C}} \mathrm{RDI}\right), 80.85 \mathrm{~kg}^{-1}$ tree $\left(50 \% \mathrm{ET}_{\mathrm{C}} \mathrm{PRD}\right)$, and $66.1 \mathrm{~kg}$ tree $^{-1}$ (rainfed). The WUE was significantly higher in the deficit irrigation treatments as compared to $100 \% \mathrm{ET}_{\mathrm{C}}$ treatment. The PRD irrigated mangos had a bigger average fruit size and a more favourable fruit size distribution.

According to the findings, there were no significant differences among productivity, number of fruits per plant, and fruit size in none of the irrigation treatments subjected. Therefore, controlled deficits can be applied at any stage of the fruit development. The average values of $\Psi_{\text {stem }}$ varied between -0.90 and $-1.74 \mathrm{MPa}$, evidencing significant effect for $\mathrm{T}_{1}$ (without irrigation), $\mathrm{T}_{7}$ and $\mathrm{T}_{8}$ (RDI with $30 \% \mathrm{ET}_{\mathrm{C}}$ in the phases II and III, respectively).

The RDI supplying $50 \%$ of the $\mathrm{ET}_{\mathrm{C}}$ during phase I and II provided larger root length density. The highest root density was found from 0.50 to $1.50 \mathrm{~m}$ distance from the trunk and at 0.20 and $0.90 \mathrm{~m}$ soil depth. The application of RDI during fruit set does not influence either root distribution or yield. Root system and fruit yield was significantly reduced under no irrigation conditions.

The water deficit caused photosynthesis rate reduction of leaves, $\mathrm{RDI} 50 \% \mathrm{ET}_{\mathrm{C}}$ at fruit physiological ripening phase resulted in higher yield and better WUE, and RDI 50\% $\mathrm{ET}_{\mathrm{C}}$ during the fruit set phase and no irrigation caused significant yield reduction. The use of RDI with $50 \% \mathrm{ET}_{\mathrm{C}}$ in the III phase of fruit development provided fruits with $350 \mathrm{~g}$ weight class.

No significant difference among photosynthetically active radiation, leaf temperature, internal $\mathrm{CO}_{2}$ concentration, transpiration, stomatal conductance, photosynthesis, carboxylation efficiency, and quantum efficiency of photosynthesis, among other indices in full irrigation and PRD strategies. PRD at $40 \% \mathrm{ET}_{\mathrm{C}}$ did not cause interference in gas exchange, maintaining fruit yield and increasing WUE.

Photosynthesis, carboxylation efficiency, and quantum efficiency of photosynthesis were lower in $\mathrm{PRD} 40 \% \mathrm{ET}_{\mathrm{C}}$ compared to full irrigation and $\mathrm{PRD} 80 \% \mathrm{ET}_{\mathrm{C}}$. Phases of expansion and fruit ripening $\left(\mathrm{P}_{\mathrm{II}}\right.$ and $\left.\mathrm{P}_{\mathrm{III}}\right)$ are more appropriate for application of RDI with 50 and $75 \% \mathrm{ET}_{\mathrm{C}}$ without important adverse effects on 
Table 1 (continued)

\begin{tabular}{|c|c|c|}
\hline Author & Aim of study & Main findings \\
\hline & $\begin{array}{l}\text { combinations of phases, and PRD at } 100,80,60 \text {, and } 40 \% \mathrm{ET}_{\mathrm{C}} \\
\text { in three phases. }\end{array}$ & $\begin{array}{l}\text { yield losses and greater WUE. PRD with } 15 \text {-day alternation at } \\
40 \% \mathrm{ET}_{\mathrm{C}} \text { registered greater WUE. }\end{array}$ \\
\hline $\begin{array}{l}\text { Faria et al. } \\
\qquad(2016)\end{array}$ & $\begin{array}{l}\text { Assessment of irrigation reduction for floral induction } \\
\text { management and productivity at flowering }\left(\mathrm{F}_{\mathrm{I}}\right) \text { and fruiting }\left(\mathrm{F}_{\mathrm{II}}\right) \\
\text { stages by effect: } 0 \% \text { in } \mathrm{F}_{\mathrm{I}} \text { and } 100 \% \mathrm{ET}_{\mathrm{C}} \text { in } \mathrm{F}_{\mathrm{II}}\left(\mathrm{T}_{1}\right) ; 25 \% \text { in } \mathrm{F}_{\mathrm{I}} \\
\text { and } 100 \% \mathrm{ET}_{\mathrm{C}} \text { in } \mathrm{F}_{\mathrm{II}}\left(\mathrm{T}_{2}\right) ; 50 \% \text { in } \mathrm{F}_{\mathrm{I}} \text { and } 100 \% \mathrm{ET}_{\mathrm{C}} \text { in } \mathrm{F}_{\mathrm{II}}\left(\mathrm{T}_{3}\right) ; \\
75 \% \text { in } \mathrm{F}_{\mathrm{I}} \text { and } 100 \% \mathrm{ET}_{\mathrm{C}} \text { in } \mathrm{F}_{\mathrm{II}}\left(\mathrm{T}_{4}\right) \text {; and } 100 \% \text { of } \mathrm{ET}_{\mathrm{C}} \text { in } \mathrm{F}_{\mathrm{I}} \text { and } \\
\mathrm{F}_{\mathrm{II}}\left(\mathrm{T}_{5}\right)\end{array}$ & $\begin{array}{l}\text { Irrigation reduction affected floral induction by lowering rates of } \\
\text { photosynthesis, transpiration, and leaf-water potential in the } \\
\text { flowering stage. Productive characteristics were not affected by } \\
\text { irrigation reduction, particularly during the evaluated cycles. } \\
\text { Irrigation reduction at } 0 \% \text { or } 25 \% \mathrm{ET}_{\mathrm{C}} \text { in the flowering stage }\left(\mathrm{T}_{1}\right. \\
\text { and } \mathrm{T}_{2} \text { ) and } 100 \% \mathrm{ET}_{\mathrm{C}} \text { in the fruiting phase were suitable for } \\
\text { floral induction. }\end{array}$ \\
\hline $\begin{array}{l}\text { Subbaiah } \\
\text { et al. } \\
\quad(2017)\end{array}$ & $\begin{array}{l}\text { Evaluated the effects of PRD and RDI strategies on mango yield } \\
\text { and fruit quality under no irrigation }\left(\mathrm{T}_{1}\right) \text {, RDI at } 100 \% \\
\text { evaporation }(\mathrm{EP})\left(\mathrm{T}_{2}\right), \mathrm{RDI} \text { at } 75 \% \mathrm{EP}\left(\mathrm{T}_{3}\right), \mathrm{RDI} \text { at } 50 \% \mathrm{EP} \\
\left(\mathrm{T}_{4}\right), \text { PRD at } 50 \% \mathrm{EP}\left(\mathrm{T}_{5}\right) \text {, and PRD at } 75 \% \mathrm{EP}\left(\mathrm{T}_{6}\right)\end{array}$ & $\begin{array}{l}\left.\text { Maximum fruit yield (52.9 and } 50.0 \mathrm{~kg} \text { tree }{ }^{-1}\right) \text { and fruit weight } \\
(379.0 \text { and } 360.0 \mathrm{~g}) \text { were found in } \mathrm{T}_{2} \text { during two monitoring } \\
\text { seasons. Maximum total sugars }(16.7 \text { and } 17.1 \%) \text { were obtained } \\
\text { with } \mathrm{T}_{6} \text { and maximum reducing sugars }(5.5 \text { and } 5.8 \%) \text { with } \mathrm{T}_{5} \text {. } \\
\text { Highest relative water content was noticed with } \mathrm{T}_{2} \text { throughout } \\
\text { the irrigation period and the lowest with } \mathrm{T}_{1} \text {. }\end{array}$ \\
\hline $\begin{array}{l}\text { Cotrim et al. } \\
\text { (2017) }\end{array}$ & $\begin{array}{l}\text { Evaluated the effects of controlled soil-water deficit by RDI on } \\
\text { fruit yield, WUE and } \Psi_{\text {stem }} \text { dynamics; deficits were applied } \\
\text { during fruit development stage with } 10 \text { and } 8 \text { treatments during } \\
\text { first and second year, respectively }\end{array}$ & $\begin{array}{l}\text { Soil-water potential in treatments subjected to RDI varied from } 0 \text { to } \\
-0.010 \mathrm{MPa} \text { between saturation and field capacity. } \Psi_{\text {stem }} \text { ranged } \\
\text { from }-0.83 \text { to }-1.62 \mathrm{MPa} \text {, with lower values in non-irrigated } \\
\text { and with RDI } 30 \% \mathrm{ET}_{\mathrm{C}} \text { in phases II and III. Mango productivity } \\
\text { and fruit quality were not affected by deficit irrigation } \\
\text { treatments. }\end{array}$ \\
\hline
\end{tabular}

Overall, plant-based water stress indicators have an advantage over soil-based ones, as they can perceive water stress due to the cumulative effect of low soil-water availability and increased atmospheric water demand. In general, plants can tolerate water stress only up to a threshold level, and beyond which a severe reduction in yield takes place.

Plants respond and adapt under water stress by inducing diverse complex morphological, biochemical, and physiological responses (Fig. 2). In this sense, relative water content, $\Psi_{\text {leaf }}$ or $\Psi_{\text {stem }}$, stomatal conductance $\left(\mathrm{g}_{\mathrm{S}}\right)$, transpiration rate, and leaf or canopy temperature, among others, are key parameters that affect the plant-water relationship (Landsberg et al. 2017). It has been suggested that $\Psi_{\text {leaf }}$ is a less reliable measure for irrigation scheduling decisions for fruit trees than $\Psi_{\text {stem }}$ due to its inherent variability under field conditions. In this regard, Naor $(2000,2004)$ found that $\Psi_{\text {stem }}$ was more sensitive than $\Psi_{\text {leaf }}$ as it showed a high correlation with fruit weight and yield using measurements of apple, nectarine, lychee, grapevine, and plum. Other subtropical fruit such as avocado and according to Chartzoulakis et al. (2002) the predawn $\Psi_{\text {leaf }}$ declined by $-0.9 \mathrm{MPa}$ for cv. Fuerte and 1.2 MPa for cv. Hass by effect of water stress, whereas the turgor potential remained positive due to a decrease in the osmotic potential in both cultivars. Tissue elasticity seems to be the predominant physiological mechanism of drought adaptation of avocado, being cv. Hass appears to be more affected by moderate water stress. Similar, avocado trees reached a minimum $\Psi_{\text {stem }}$ of $-0.9 \mathrm{MPa}$ and maximum daily trunk shrinkage around $285 \mu \mathrm{m}$, being that this latter indicator is more sensitive in detecting water stress (Celedón et al. 2012).
Parameters such as trunk diameter and sap flow are also used to assess water status. In concordance with this, Lu et al. (2000) investigated circumferential and radial changes in xylem sap flux density in mango trunks using Granier sap flow sensors with full irrigation or a withheld water supply. They showed that the relationships among some parameters were constant but variable under changing soil-water conditions. Sap flow density showed considerable variation within the trunk and an important flux was observed at its centre. Based on their findings, they described a method for calculating total sap flow in a mango tree from sap flux density at $0-2 \mathrm{~cm}$ beneath the cambium. According to $\mathrm{Lu}$ (2005), irrigation controlled by dendrometers using the shrinkage index as an indicator had better irrigation efficiency than full irrigation of trees, amounting to $77 \%$ of irrigation water used by mango trees. Therefore, both the dynamics of sap flow (tree water use) and twig/branch shrinkage may be good plant-based indicators of plant water status and could potentially be used to control water stress and irrigation.

In agreement with Pongsomboon (1991), the $\Psi_{\text {leaf }}$ dynamics and behaviour under water stress revealed that mango trees exhibit a degree of drought tolerance. Nadler et al. (2006) reported that $\Psi_{\text {leaf }}$ could be considered an adequate water stress indicator, although it varies throughout the day because it recovers regular plant water status during the night, as is typical in fruit trees. More evidence of the effect of water stress was noted by Larson et al. (1989), who reported that predawn $\Psi_{\text {leaf }}$ with an irrigation regime that included a 7-day interval $(100.6 \mathrm{~mm})$ remained nearly constant at $-0.30 \mathrm{MPa}$, 
Table 2 Main regulated sustained deficit irrigation (SDI) studies in mango cultivation

Author Aim of study Main findings

Da Silva et al. Water requirements, yield, and WUE by sprinkler irrigation system based (2009) on irrigation levels: $70 \% \mathrm{ET}_{0}\left(\mathrm{~T}_{1}\right), 80 \% \mathrm{ET}_{0}\left(\mathrm{~T}_{2}\right), 90 \% \mathrm{ET}_{0}\left(\mathrm{~T}_{3}\right)$, and $100 \% \mathrm{ET}_{0}\left(\mathrm{~T}_{4}\right)$

Durán et al. Examined the response of fruit yield and WUE to three SDI treatments: (2011) $\mathrm{SDI}_{1}\left(75 \% \mathrm{ET}_{\mathrm{C}}\right), \mathrm{SDI}_{2}\left(50 \% \mathrm{ET}_{\mathrm{C}}\right)$, and $\mathrm{SDI}_{3}\left(33 \% \mathrm{ET}_{\mathrm{C}}\right)$, compared with a control at $100 \% \mathrm{ET}_{\mathrm{C}}$

Bhriguvanshi et al. $(2012$, 2013)

Impact of irrigation levels on mango yield based on replenishment of 90, 70 , and $60 \%$ open pan-evaporation (OPE) and basin irrigation as control, and fertigation at 75 and $50 \%$ of recommended doses of $\mathrm{N}$ and no

Schulze et al. (2013)

Bhriguvanshi et al. (2015)

Effects on yield and WUE of irrigation scheduling consisted of OPE replenishment (90, 70 and $60 \%$ of OPE) under drip irrigation system and basin irrigation as control associated with three $\mathrm{N}$ levels (75 and 50\% of recommended dose of $\mathrm{N}$ and no fertigation as control) fertigation as control

The ET and WUE were strongly influenced by soil-water availability. Mango yield varied from 28.06 $\left(\mathrm{T}_{4}\right)$ to 31.06 tonnes ha ${ }^{-1}$ in treatment $\left(\mathrm{T}_{3}\right)$. The WUE based on irrigation and evapotranspiration were from $5.1\left(100 \% \mathrm{ET}_{0}\right)$ to $8.0 \mathrm{~kg} \mathrm{~m}^{-3}\left(70 \% \mathrm{ET}_{0}\right)$ throughout the study period.

The $\mathrm{SDI}_{2}$ proved to be the most appropriate, since it allowed the trees to reach the highest yield (18.4 tonnes $\left.\mathrm{ha}^{-1}\right)$ and with the best WUE $\left(7.14 \mathrm{~kg} \mathrm{~m}^{-3}\right)$. The fruit size was higher for $\mathrm{SDI}_{3}$ and control trees $\left(100 \% \mathrm{ET}_{\mathrm{C}}\right)$, being they reached significantly higher length and width. The TSS was the highest in fruits from $\mathrm{SDI}_{1}$ and $\mathrm{SDI}_{2}$ plots.

Drip irrigation irrespective of fertigation significantly increased fruit yield and plant nutrient contents over basin irrigation. Drip irrigation at 60\% OPE was found to be the best system for maintaining optimum soil moisture, yield and significant spatial distribution of plant nutrients.

Fruit yield from 90, 70, and 60\% OPE was higher than with basin irrigation at $19.4,40.5$, and $57.5 \%$. WUE ranged from 9.9 to $18.8 \mathrm{~kg} \mathrm{~m}^{-3}$ for drip irrigation and was $7.0 \mathrm{~kg} \mathrm{~m}^{-3}$ for basin irrigation.

According to the findings, the marketable yield of mango fruits increased substantially ( $31 \%$ increase in class I fruits larger $300 \mathrm{~g}$ ) with improved irrigation, particularly during a drought year; it is worthwhile to change traditional irrigation into modern, water-efficient, and flexible systems. The DI increases the crop water productivity substantially and stabilises yield during drought years. The profit can be increased by $55 \%$ under FI with micro-sprinklers.

The drip irrigation increased fruit yield and WUE over traditional basin irrigation system. The increase in fruit yield with respect to basin irrigation was 12.2, 42.5 , and $47.9 \%$ by 90,70 , and $60 \%$ OPE, respectively. The WUE ranged between 5.25 and $9.94 \mathrm{~kg} \mathrm{~m}^{-3}$ in the drip irrigations and amounted to $3.69 \mathrm{~kg} \mathrm{~m}^{-3}$ for basin application. Moreover, the water irrigation savings by drip irrigation reached $21.1,35.4$, and $45.2 \%$ in 90,70 , and $60 \%$ OPE, respectively.

Heryani et al. Examined the effects on productivity and fruit quality of irrigation regimes (2016) (fan jet sprayer): $125 \%, 100 \%, 75 \%, 50 \%$, and $0 \%$ of crop water requirements, equal to $828,663,497,331$, and $0 \mathrm{~L}$ tree ${ }^{-1}$ applied every 7 days

Irrigation at 50 and $75 \%$ of crop water requirement had the most and least fallen fruits (26 and $14 \%$ of total production), respectively. Highest and lowest total fruits were 3108 and 1904 , achieved at 50 and $75 \%$ of crop water requirement, respectively. Highest and lowest total weight of fruits was 1036.2 and $677.9 \mathrm{~kg}$ harvested from irrigation at 50 and $125 \%$ of crop water requirement, respectively. Mango fruits produced were dominated by grades 2 and 3 with $\mathrm{A}$ quality.

Wei et al. (2017)
Effects of irrigation on yield and fruit quality based on soil-water content criteria ( $\%$ of field water capacity) were compared: $\mathrm{T}_{1}, 79-82 \% ; \mathrm{T}_{2}$, $75-78 \% ; \mathrm{T}_{3}, 71-74 \% ; \mathrm{T}_{4}, 65-70 \%$; and $\mathrm{T}_{5}, 63-66 \%$
Highest fruit yield and WUE were obtained from $\mathrm{T}_{4}$. Irrigation amount affected fruit quality parameters (total soluble solids, soluble sugar, starch, titratable acid, and vitamin $\mathrm{C}$ content). Therefore, soil moisture content at $65-70 \%$ of field water moisture capacity could ensure maximum production efficiency of irrigation and the best fruit quality. 
Table 2 (continued)

\begin{tabular}{|c|c|c|}
\hline Author & Aim of study & Main findings \\
\hline $\begin{array}{l}\text { Darwish and } \\
\text { El-soufany } \\
(2017)\end{array}$ & $\begin{array}{l}\text { Impact of irrigation regimes on tree growth, yield, and fruit quality by } \mathrm{T}_{1} \text { at } \\
100 \% \text { of available water as control; } \mathrm{T}_{2}, 85 \% \text { of } \mathrm{T}_{1} ; \mathrm{T}_{3}, 75 \% \text { of } \mathrm{T}_{1} \text {; and } \\
\mathrm{T}_{4}, 60 \% \text { of } \mathrm{T}_{1}\end{array}$ & $\begin{array}{l}\mathrm{T}_{2} \text { treatment proved to be the most appropriate, with the } \\
\text { highest mango fruit yield }\left(6360.9 \mathrm{~kg} \mathrm{fed}^{-1}\right) \text { and best } \\
\text { WUE }\left(1.13 \mathrm{~kg} \mathrm{~m}^{-3}\right) ; \text { by contrast, } \mathrm{T}_{4} \text { harvested the } \\
\text { lowest fruit yield }\left(2166.6 \mathrm{~kg} \mathrm{fed}^{-1}\right) \text { and WUE } \\
\left(0.55 \mathrm{~kg} \mathrm{~m}^{-3}\right) \text { throughout the study period. }\end{array}$ \\
\hline Khalifa (2018) & $\begin{array}{l}\text { Assessed the impact of irrigation on yield, fruit quality, and WUE based on } \\
100,80 \text {, and } 60 \% \mathrm{ET}_{\mathrm{C}}\end{array}$ & $\begin{array}{l}\text { Irrigation at } 80 \% \mathrm{ET}_{\mathrm{C}} \text { increased the number of fruits per } \\
\text { tree, yield, and WUE, but worsened fruit quality; } 60 \% \\
\mathrm{ET}_{\mathrm{C}} \text { treatment caused a decrease in total yield due to } \\
\text { water stress but improved fruit quality. }\end{array}$ \\
\hline $\begin{array}{l}\text { Shah et al. } \\
\text { (2018) }\end{array}$ & $\begin{array}{l}\text { Evaluated the effects of drip irrigation (with emitters of } 4 \mathrm{~L} \mathrm{~h}^{-1} \text { ) applied } \\
\text { twice per day on growth and fruit yield: } \mathrm{T}_{1}, 12.5 \mathrm{~min} ; \mathrm{T}_{2}, 25 \mathrm{~min} ; \mathrm{T}_{3} \text {, } \\
37.5 \mathrm{~min} ; \mathrm{T}_{4}, 50 \mathrm{~min} ; \mathrm{T}_{5}, 62.5 \mathrm{~min} ; \mathrm{T}_{6}, 75 \mathrm{~min} \text {; and } \mathrm{T}_{7}, 87.5 \mathrm{~min}\end{array}$ & $\begin{array}{l}\text { Maximum plant height, number of flowers, fruits per } \\
\text { tree, fruit length, and fruit yield were recorded in } \mathrm{T}_{5} \text {; } \\
\text { maximum plant girth and fruit weight were found in } \\
\mathrm{T}_{6} \text {, and } \mathrm{T}_{1} \text { showed poor results. }\end{array}$ \\
\hline $\begin{array}{c}\text { Shyam et al. } \\
\text { (2019) }\end{array}$ & $\begin{array}{l}\text { Responses of yield and fruit quality to mulching and no mulching; two } \\
\text { irrigation levels, } 100 \% \text { recommended irrigation (RI) and 75\% RI; and } \\
\text { three fertilizer levels, } 100 \% \text { recommended dose of fertilizer (RDF), } 75 \% \\
\text { RDF, and } 50 \% \text { RDF }\end{array}$ & $\begin{array}{l}\text { Findings revealed that mulch significantly increased fruit } \\
\text { set, retention, yield, and quality. Maximum yield } \\
\left(23.24 \text { tonnes ha }{ }^{-1} \text { ) was obtained under 75\% RI with }\right. \\
100 \% \text { RDF, at par with 75\% RI and 75\% RDF. } \\
\text { Mulching significantly improved the } \\
\text { physico-chemical soil parameters. }\end{array}$ \\
\hline
\end{tabular}

WUE, water use efficiency; $* f e d, 4200 \mathrm{~m}^{2}$; TSS, total soluble solids

in contrast with trees without irrigation, for which the value decreased after 1 week, not reaching less than -0.50 MPa.

Saxena et al. (2017) evaluated the effect of paclobutrazol (a growth retardant with anti-gibberellin activity that can induce flowering) on mango cvs. Amrapali and Langra and their responses to different levels of water stress. During flower bud differentiation, cv. Amrapali had higher osmotic potential than cv. Langra ( -3.39 and $-5.56 \mathrm{MPa}$, respectively). However, osmotic potential increased substantially in trees treated with paclobutrazol at the flower bud and panicle emergence stages with respect to control trees. Moreover, sap flow also changed significantly, as cv. Amrapali (6.7-18.9 $\mathrm{kg} \mathrm{h}^{-1}$ ) had a higher range than cv. Langra $\left(6.9-13.1 \mathrm{~kg} \mathrm{~h}^{-1}\right)$. Therefore, the adjustment to water stress by cv. Amrapali and its osmoregulation presumably makes it more adequate for subtropical conditions.

On the other hand, Zaharah and Razi (2009) and De Ollas et al. (2015) claimed that leaf growth, g , proline concentration, peroxidase activity, ABA and jasmonic acid (JA) levels, and anatomical changes could be used as parameters to test water stress more accurately. In other words, these parameters were thought to be required to obtain more robust evidence regarding plant water status, considering that plants exhibit great variation in morphological, physiological, and biochemical characteristics related to water stress tolerance.

Damour et al. (2009) studied the effect of water stress on the depletion of photosynthetic capacity in mango leaves, finding that not only is photosynthesis limited by stomatal closure ( $g_{S}$ rates), but it is also downregulated by maximal net photosynthesis $\left(\mathrm{A}_{\mathrm{N}}\right)$ and the light-saturated rate of photosynthetic electron transport. Moreover, the hexose/sucrose ratio was higher in leaves from water-stressed trees than in control leaves, suggesting that photosynthetic capacity was reduced due to a sink limitation. Dos Santos et al. (2014b) reported a significant reduction in photosynthesis rate due to water stress provoked by deficit irrigation in mango trees that could be ascribed to stomatal closure, since this mechanism preserves physiological water by transpiration reduction and restriction of $\mathrm{CO}_{2}$ assimilation.

Morphological and physiological parameters of mango were evaluated by Luvaha et al. (2008), who concluded that the increased water stress reduced the gas exchange rate in mango and increased the leaf chlorophyll content due to an adaptive mechanism. Furthermore, water stress results in progressively decreased leaf relative water content, $\mathrm{A}_{\mathrm{N}}, \mathrm{g}_{\mathrm{S}}$, and increased conversion of xanthophyll cycle pigments (carotenoid/chlorophyll ratio, non-photochemical quenching, malondialdehyde, and compatible solutes - total soluble sugar and proline), with this effect being more pronounced in mango plants in full sunlight than those in 50\% sunlight (Elsheery and Cao 2008). Therefore, partial shading ( $50 \%$ sunlight) significantly alleviated the harmful effect of water stress on mango, but the stomata of plants grown in partial shade were more responsive to water deficit than those in full light. That is, mango trees accumulate certain compounds in the cells as a protection against water stress. This is in line with Turner (1979), who reported that the accumulation of osmolyte compounds (proline and sugars) in the cells as a consequence of water stress may be associated with a mechanism to tolerate the 
Fig. 2 Main physiological mechanisms to face water stress in mango tree. ATP, adenosine triphosphate; ABA, abscisic acid; JA, jasmonic acid; $\uparrow$, increase; $\downarrow$, decrease

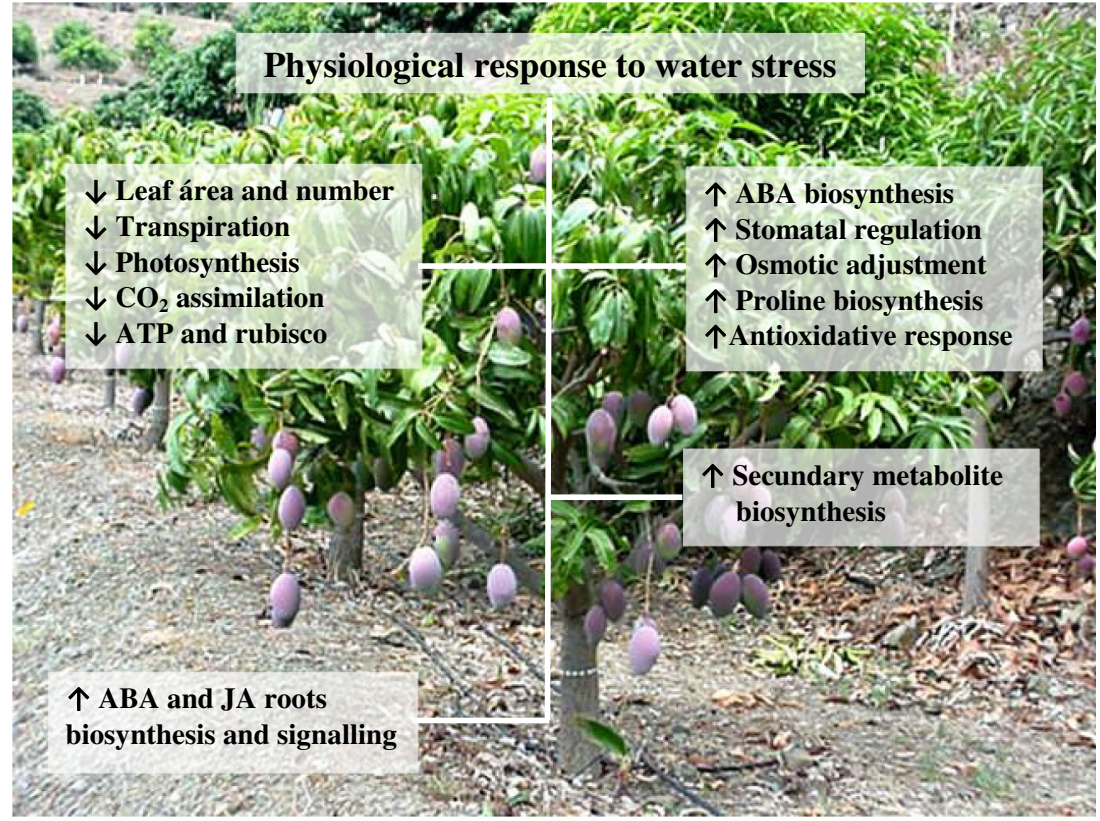

harmful effect of water stress. Thus, water stress reduces the growth rate of different plant organs, disturbs the plantwater relationship, and reduces water use efficiency.

Cotrim et al. (2011) determined $\Psi_{\text {stem }}$ values at midday ranging between -0.90 and $-1.74 \mathrm{MPa}$ for non-stressed and water-stressed trees, respectively, while Castro et al. (2004) recorded leaf petiole values between -0.30 and $1.70 \mathrm{MPa}$ and Lima (2004) determined $\Psi_{\text {leaf }}$ within a greater range from -0.30 to $-1.73 \mathrm{MPa}$. Pavel et al. (2003) reported that $\Psi_{\text {stem }}$ values for non-stressed mango trees fluctuated between -0.4 and $-0.6 \mathrm{MPa}$ over the season in a subtropical climate, and the stress responses to water deficits were detected first by $\Psi_{\text {stem }}$, followed by $g_{S}$, indicating that they are more sensitive stress indicators than $A_{N}$. Thus, in general terms, the seasonal pattern at different phenological stages of mango development has a correlation with seasonal variation in tree water status.

Jabri and Yahyai (2017) studied the soil-water retention curve and mango tree water status, stating that the response of $\Psi_{\text {leaf }}$ was not so evident, nor was visual physical signs of low soil-water levels. They also reported that mango is relatively tolerant by making adjustments to internal physiological functions, and water stress was better exhibited by the soilwater retention curve than $\Psi_{\text {leaf }}$ In this context, Dos Santos et al. (2013) claimed that a total or partial soil-water deficit provoked a reduction in $\mathrm{A}_{\mathrm{N}}$, transpiration, and $\mathrm{g}_{\mathrm{S}}$ of leaves as a result of different RDI strategies applied. However, the partial soil-water deficit did not trigger significant alterations to the internal $\mathrm{CO}_{2}$ concentration or in the leaf temperature of mango trees. Therefore, plant physiological responses are not regulated solely by soil-water availability solely, but by a complex interaction of intrinsic and extrinsic factors.
Figure 3 shows the daily response of $\Psi_{\text {leaf }}$ and $g_{S}$ throughout the growing cycle of mango cv. Osteen subjected to different SDI strategies in a Mediterranean subtropical environment. The significant alterations in the dynamics of both physiological parameters were in accordance with the amount of water irrigation applied to non-stressed $\left(100 \% \mathrm{ET}_{\mathrm{C}}\right)$ and severely water-stressed $\left(33 \% \mathrm{ET}_{\mathrm{C}}\right)$ trees. Higher average daily values for $\Psi_{\text {leaf }}$ were found at 16:00, when the evaporative demand reached its daily peak, ranging from $-0.49\left(100 \% \mathrm{ET}_{\mathrm{C}}\right)$ to $-1.10 \mathrm{MPa}\left(33 \% \mathrm{ET}_{\mathrm{C}}\right)$. Despite the great variability of $\Psi_{\text {leaf }}$, the behaviour of the most severe SDI treatment contrasted markedly to that of control trees. Similarly, the $\mathrm{g}_{\mathrm{S}}$ rate registered a decreasing trend at 16:00, except during day of the year (DOY) 119. The maximum $\mathrm{g}_{\mathrm{S}}$ rate at midday was fixed in control trees at $98.2 \mathrm{mmol} \mathrm{m}^{-2} \mathrm{~s}^{-1}$, while for the severe SDI treatment, it was $30.0 \mathrm{mmol} \mathrm{m}^{-2} \mathrm{~s}^{-1}$, as water stress caused stomatal closure that inevitably provoked an increased leaf temperature. Overall, in well-watered as well as in water-stressed mango trees, stomatal conductance peaked early in the morning, and then declined; however, sometimes there was a slight recovery later in the afternoon.

Stomata are pores disposed on leaf surfaces through which plants exchange water vapour, $\mathrm{CO}_{2}$, and other components with the surrounding environment. Under any given conditions, water stress induced by deficit irrigation result in stomatal closure and a decline in the transpiration rate. It is well known that stomatal density responds to environmental factors and water deficit leads to an augmentation in stomatal density and a reduction in stomatal size, exhibiting an adaptation to water shortage. In this context, Dos Santos et al. (2015) highlighted a decreasing trend in $\mathrm{g}_{\mathrm{S}}$ rates due to water stress 
$\Psi_{\text {leaf }}$

(MPa)
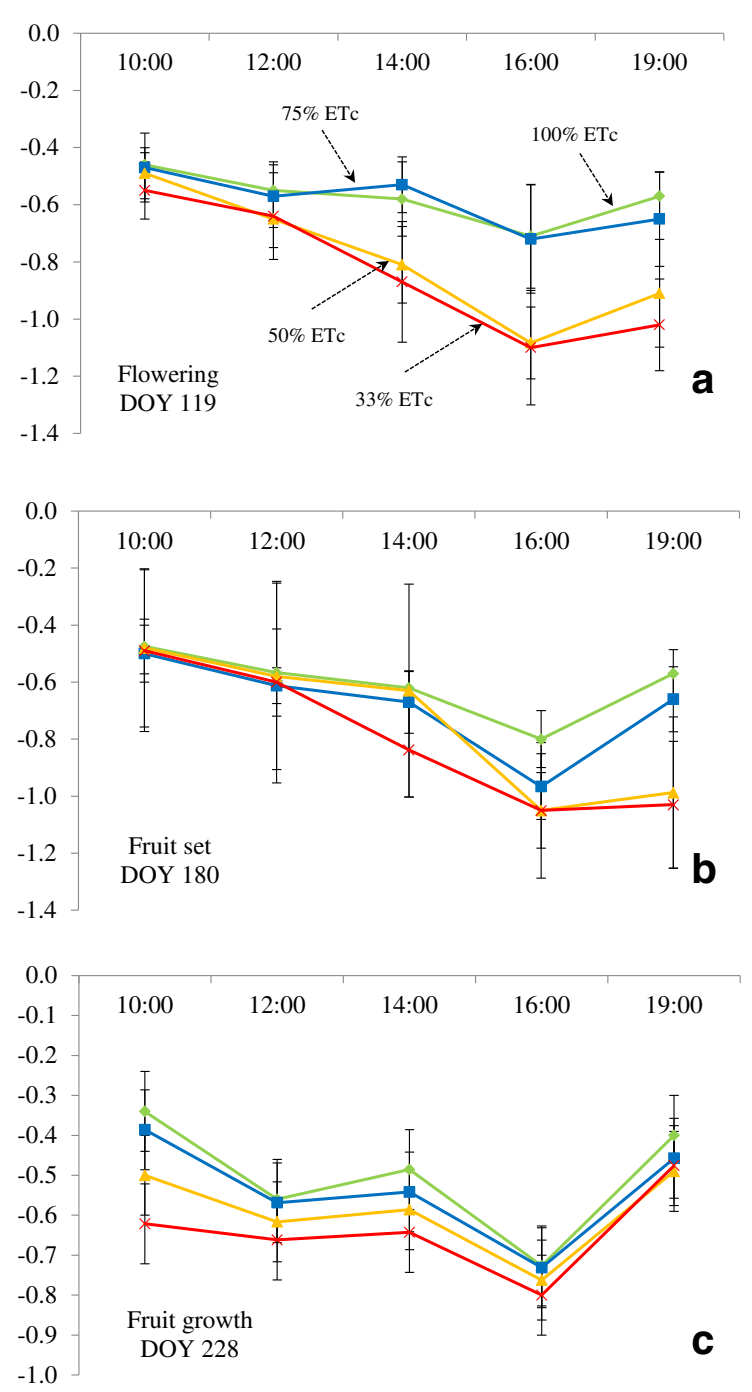

$\underset{(\mathrm{mmol} \mathrm{m}}{\left.\mathrm{g}_{\mathrm{S}} \mathrm{s}^{-1}\right)}$
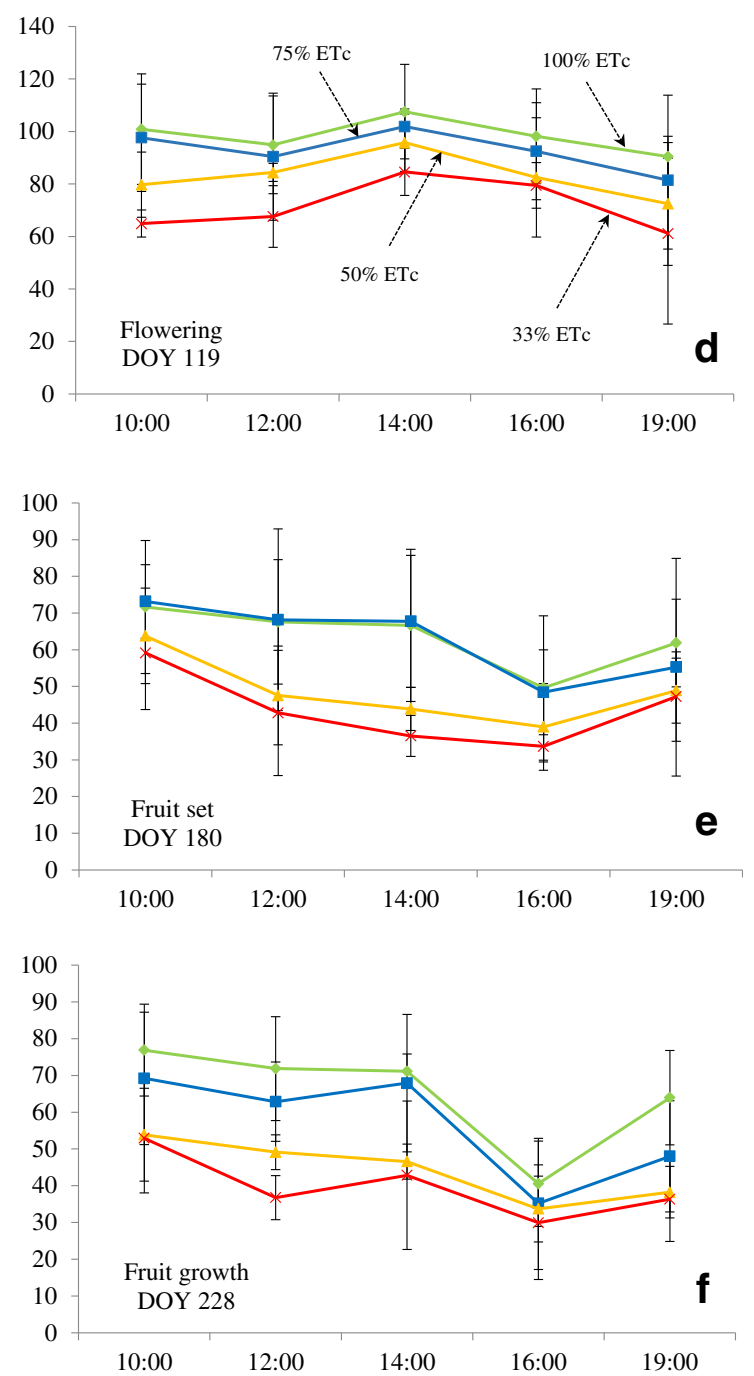

Fig. 3 Average daily dynamics of leaf-water potential $\left(\Psi_{\text {leaf }}\right)(\mathbf{a}, \mathbf{b}$, and $\mathbf{c})$ and stomatal conductance $\left(\mathrm{g}_{\mathrm{S}}\right)(\mathbf{d}$, e, and $\mathbf{f})$ throughout the main mango phenological stages by effect of SDI strategies. DOY, day of the year. Vertical bars are standard deviation of 5 replicate leaf samples

under PDR strategies from control trees (PDR $100 \% \mathrm{ET}_{\mathrm{C}}$ ) to severely water-stressed trees (PRD 40\% $\mathrm{ET}_{\mathrm{C}}$ ) of 190.0 and $130 \mathrm{mmol} \mathrm{m}^{-2} \mathrm{~s}^{-1}$, respectively.

In short, water stress indicators can be used to perceive and measure the water stress level in mango subjected to different water deficit levels, as for most works cited in this review, the results were consistent with yield results. However, the limited number of published studies highlights the need to determine physiological threshold values, which can only be found through a deeper understanding of mango response to water stress. Determining the threshold values of water stress indicators is crucial to finding the threshold water stress level at which mango can be irrigated without having an injurious impact on crop growth and fruit yield. In addition, plant-based water stress indicators could be helpful in screening for drought-tolerant mango cultivars.

\section{Towards sustainable subtropical mango cultivation-a Spanish case study}

Mango fruit production is possible on the coast of Granada and Malaga (SE Spain) despite the high latitude, which represents the northern limit for commercial development of the crop. Cultivation in the coastal strip is possible because of the high mountains bordering from east to west, which block the northern cold winds. An intensive irrigated agricultural system was established based on tropical and subtropical crops in the mountainous areas near the coast in the form of machine-constructed terraces (Fig. 4) (Durán et al. 2013, 2020). These new structures have deeply changed the traditional landscape of this region, as traditional terraces were built by hand and on stone. Additionally, the urban and demographic pressure in these coastal provinces (mainly due to 
Fig. 4 Irrigated mango plantation in terraces in Mediterranean subtropical area (SE, Spain)

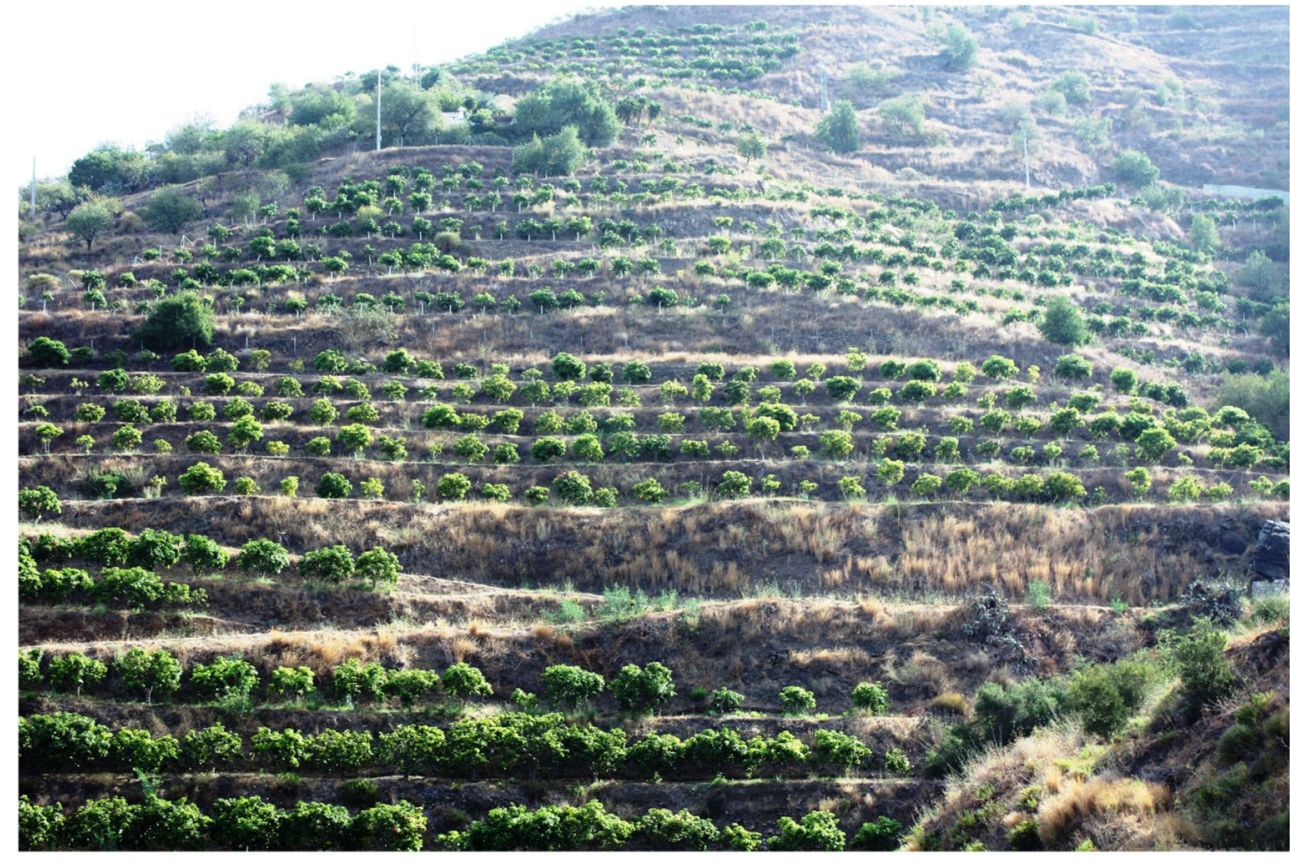

the growth of tourism) interacts with the use of the two main resources of the area: soil and water.

During the period 2015-2019, the average price per kilogramme of mangos amounted to $€ 1.21$ for farmers (OPM 2020). The average mango yield in Malaga and Granada plantations for 2018 was 9.0 and 10.3 tonnes $\mathrm{ha}^{-1}$, with a total fruit production of 31,500 and 1473 tonnes, respectively. In 2018, Spain exported 48,000 tonnes (96\% of total production) to the EU, with the main importer being Portugal (31\%), followed by France and Germany, with $21 \%$ and $13 \%$, respectively (OPM 2020). Spain imports mango throughout the year to complement its own production, with its main suppliers being Peru (7800 tonnes) and Brazil (7500 tonnes).

The main cultivars in this area mostly have red skin upon maturity, ranging from orange to purple, and the predominant mango is cv. Osteen, which occupies two-thirds of the devoted area, followed by cvs. Keitt, Kent, and Tommy Atkins (Fig. 5), and the production period lasts from mid-August to the end of November. There is a peak from mid-September to mid-October due to the production of cv. Osteen. In some areas, the cultivation of cv. Keitt is possible, which makes late production until December feasible (Durán and Franco 2006). Mango fruits imported from overseas are usually harvested unripe before finally reaching the European market, and frequently lack the taste, scent, and bioactive components that are highly appreciated by European consumers. Distinctively, Spain offers commercial-quality tree-ripened fruits that can be delivered to the European market from the fields within one or 2 days. Thus, mango cultivation in south-eastern Spain offers promising possibilities for environmentally friendly production and exporting high-quality fresh fruits. However, in this type of semi-arid subtropical environment and under changing climate conditions, irrigation based on traditional practices will not be feasible in the medium or in long term. For this, the application of deficit irrigation strategies are vital to meet water scarcity conditions, and farmers should be encouraged to adapt to environmental constrains.

As argued before, agricultural land use expansion has increased the pressure on the available water in the Mediterranean area. The growing water shortage has led to an exploration of strategies for the sustainable use of irrigation water, promoting water-saving irrigation systems without a significant detrimental effect on crop production (Fig. 6). Water-saving strategies must be included in the added value of mangos produced in environmentally friendly ways such as developing labelling that will encourage consumers to switch to these new products. Furthermore, consumers are currently focused on eating a healthy diet by substituting carbohydrates and meat with diets based on fruits and vegetables, and the everyday social dimension of the product value chain is also more important.

Drought is predicted to increase because of climate change; therefore, to grow crops successfully, farmers will need to adapt to there being less for water available irrigation and take better advantage of the effects of water shortage. The positive effects associated with drought are well known. This phenomenon promotes secondary metabolism, potentially augmenting the mechanisms of plant defences and the concentrations of compounds involved in plant quality, particularly taste and health benefits. However, to manage crops properly under a limited water supply by applying deficit irrigation, farmers have to contemplate not only the impact on productivity but how plants govern their primary and secondary metabolism (Isah 2019; Llanes et al. 2018). This is complex as under an 


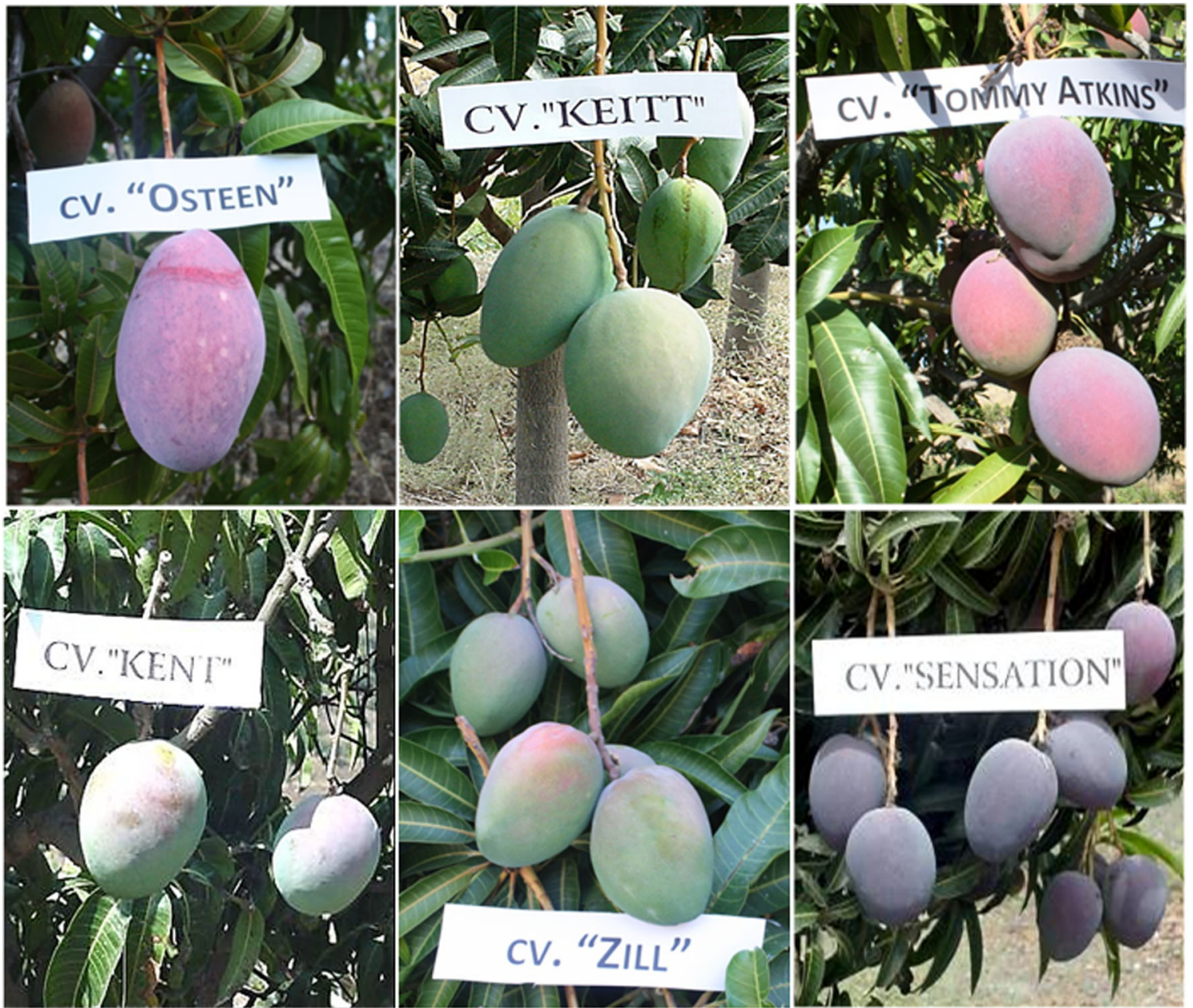

Fig. 5 Main mango Florida cultivars grown in Spanish Mediterranean subtropical area

irrigation water deficit programme, trade-offs among productivity, defence, and quality depend on the intensity, duration, and reiteration of seasons.

In this context, Martínez and Gómez (2016) highlighted that consumers are willing to pay for singular foods, especially those cultivated and associated with environmentally friendly farming practices. Noguera et al. (2016) proposed an identity brand for this type of produced food called hydroSOStainable product, which can be identified based on two main features: (1) Water deficit can increase the plant's secondary metabolite content and thus the functionality of the edible products, and (2) the products are environmentally friendly because of the sustainable use of scarce water resources. It will be crucial to establish a hydroSOStainable index in order to certify products that are produced under sustainable irrigation programmes (Corell et al. 2019). This index can assure the abovementioned features, and consumer demand would be expected to increase along with the price of hydroSOS products, and a profit increase for farmers would lead to economic benefits of deficit irrigation, further encouraging uptake of such a system. In this context, Noguera et al. (2016) reported that consumers would agree to pay a reasonably higher price for hydroSOS pistachios (Pistacia vera L.) if they were properly labelled and identified. Other published studies on hydroSOS products included Lipan et al. (2019) with almonds (Prunus dulcis L.) and Sánchez et al. (2019) with olives (Oliva europea L.). However, further research is needed to ascertain whether there would be a similar willingness to pay for fruits such as mango.

\section{Conclusions and future perspectives}

The mango tree has a wide ecological range, as shown by its vast geographic distribution in the tropics and subtropics. It has adapted to stressful conditions and has physiological mechanisms to survive in adverse environments. Overall, the water stress can be used to control shoot growth and hence flowering. The research findings suggest that moderate water stress after flowering can increase fruit production, although these gains are at the expense of fruit size. By contrast, severe water stress levels at this time reduce fruit set and yield. 


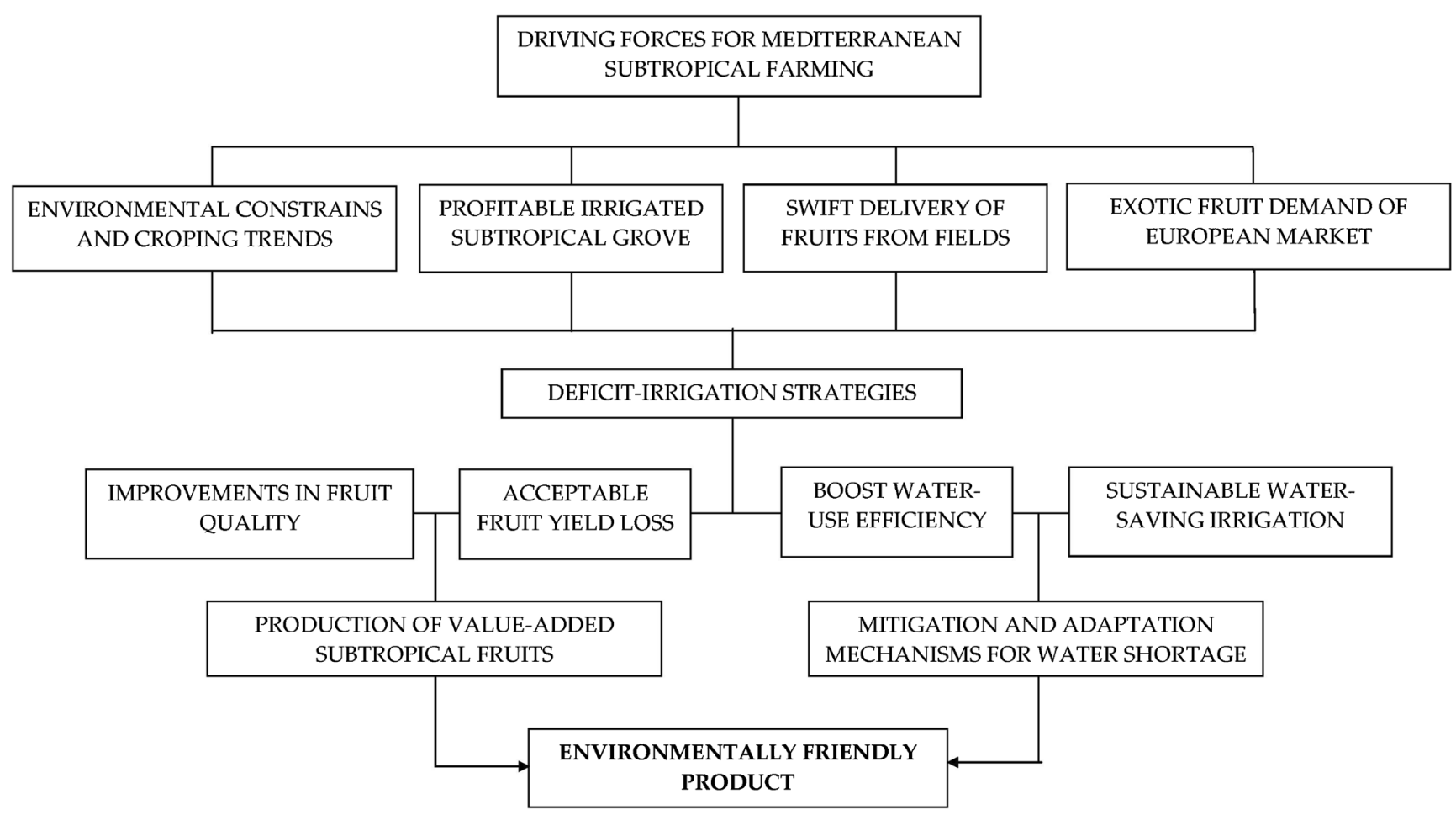

Fig. 6 Sustainable mango production frame under deficit irrigation in subtropical Mediterranean environment

Deficit irrigation techniques are key water-saving actions for the efficient use of restricted water resources for many fruit crops, and mango is no exception. However, deficit irrigation for mango demands more accurate and real-time allocation of water resources, explicitly in arid and semi-arid areas. In general, it has been determined that RDI and PRD can save irrigation water by up to $30 \%$ and up to $40 \%$, respectively, and both improve WUE by up to $30 \%$. In some cases, SDI can save water by up to $50 \%$ without having important effects on fruit yield. In light of the potential effects of climate change, farmers will need to adopt the use of alternative efficient irrigation practices. Given the importance of subtropical mango cultivation, improving our knowledge of the mango-water relationship in this particular environment is a high priority, since water is scarce and optimising irrigation use is vital.

Accordingly, semi-arid subtropical mango farming has to develop adaptive water management strategies for sustainable development, and from our perspective, some fundamental points should be taken into consideration:

(1) In a semi-arid subtropical environment and under changing climate conditions, irrigation according to traditional full irrigation based on water balance will not be sustainable in the medium/long term. This demands a redesign of irrigation practices in order to face water shortage conditions. It is therefore essential that irrigation allocation is shifted from maximum production per area to maximum production per unit of water.
(2) Deficit irrigation may be a sustainable option to attain a water-saving balance in irrigated subtropical mangoes without important losses of yield. However, it is essential to develop more detailed medium- to long-term studies to improve our knowledge of water stress management and its impact on mango vegetative growth, ecophysiology, the water relationship, yield (including alternate bearing), and fruit quality.

(3) Intensive research is needed to define the threshold values for mango by taking into consideration the environmental variations for given water stress level so that plant-based water stress indicators can be successfully implemented for irrigation scheduling.

(4) Due to limited data on subtropical mango cultivation, further research is crucial to elucidate the complex biosynthetic pathways and synthesis of nutritive- and health-related compounds and antioxidants in waterstressed trees by deficit irrigation. This knowledge will enable farmers in water-scarce zones to adopt deficit irrigation strategies not only as a tool for saving water, improving WUE, and sustaining yield but also for producing fruit with enhanced nutritive and health characteristics.

(5) Breeding programmes for new mango cultivars and rootstocks with features that will enhance water productivity through blended physiological, biotechnological, and agronomic research will be essential. 
Encouragingly, there are advances in mango production and water productivity through a combination of techniques, as shown by the studies described in this review, making it possible to implement deficit irrigation practices as a tool to achieve environmental, social, and economic benefits.

\section{Compliance with ethical standards}

Funding This publication was sponsored by the following research projects: "Innovations for sustainability, productivity, and improvement of subtropical crops (mango and cherimoya)" (AVA.AVA2019.038) co-financed by the European Regional Development Fund (ERDF) within the Operational Programme Andalusia 2014-2020 "Andalucía is moving with Europe".

Conflict of interest The authors declare no competing interest.

Ethics approval Not applicable.

Consent to participate Not applicable.

Consent for publication Not applicable.

Authors' contribution All authors contributed equally towards the research and the writing of the paper.

\section{References}

Abdel-Razik AM (2012) Effect of different irrigation regimes on quality and storability of mango fruits (Mangifera indica L.). J Hort Sci Ornam Plants 4(3):247-252. https://doi.org/10.5829/idosi.jhsop. 2012.4.3.253

Adak T, Mishra D, Kumar K, Singh VK (2019) Analysis of soil and tree productivity under high density planting system in mango cv. Dashehari (Mangifera indica L.). Trop Plant Res 6:24-30. https:// doi.org/10.22271/tpr.2019.v6.i1.005

Ahmad I, Bibi F, Ullah H, Munir MT (2018) Mango fruit yield and critical quality parameters respond to foliar and soil applications of zinc and boron. Plants 7:97. https://doi.org/10.3390/plants7040097

Ali SM, Bai K, Hanumantharaya BG, Nagraj KH (2017) Micro-catchment techniques: an effective water conservation practice in mango. Int J Curr Microbiol App Sci 6(5):2965-2969. https://doi.org/10. 20546/ijcmas.2017.605.335

Allen RG, Pereira LS, Raes D, Smith M (1998) Crop evapotranspiration guidelines for computing crop water requirements. In: FAO Irrigation and Drainage Paper 56. Rome, UN-FAO

Azzouz S, El-Nokrashyand DIM (1977) Effect of frequency of irrigation on tree production and fruit quality of mango. Agric Res Rev 55(3): 59-66

Bally ISE, Haris M, Whiley AW (2000) Effect of water stress on flowering and yield of 'Kensington Pride' mango (Mangifera indica L.). Acta Hortic 509:277-282. https://doi.org/10.17660/ActaHortic. 2000.509.30

Bally ISE (2006) Mangifera indica (mango). In: Species profiles for Pacific Island agroforestry, ver.3.1, Permanent Agriculture Resources, Hawaii, pp 1-25

Bhriguvanshi SR, Adak T, Kumar K, Singh VK, Singh A, Singh VK (2012) Impact of fertigation regimes on yield and water use efficiency of Mango (Mangifera indica L.) under subtropical condition. Indian J Soil Conserv 40(3):252-256
Bhriguvanshi SR, Adak T, Kumar K, Singh VK, Singh VK, Singh A (2013) Spatial distribution of micronutrients under different nitrogen and soil moisture regimes in drip irrigated mango (Mangifera indica L.) orchard. Curr Adv Agric Sci 5(2):230-234

Bhriguvanshi SR, Adak T, Kumar K, Singh VK, Singh VK, Singh A (2015) Drip irrigation scheduling of Mango cv. Langra under subtropical condition of Uttar Pradesh. J Soil Water Conserv 14(2): $133-140$

Blanco CF, Lourenço S, Silvestre J, Conceição N, Moñino MJ, Vivas A, Ferreira MI (2017) Plant water status indicators for irrigation scheduling associated with iso- and anisohydric behavior: vine and plum trees. Hortic 3(3):47. https://doi.org/10.3390/horticulturae3030047

Bithell SL, Diczbalis Y, Moore C (2010) Review of mango irrigation research in the Northern Territory. Northern Territory government, Australia. Technical Bulletin No 334

Buytaert W, Friesen J, Liebe J, Ludwing R (2012) Assessment and management of water resources in developing, semi-arid and arid regions. Water Resour Manag 26:841-844. https://doi.org/10.1007/ s11269-012-9994-3

Campos JHBC, Da Silva VPR, De Azevedo PV, Borges CJR, Soares JM, Moura MSB, Da Silva BB (2008) Evapotranspiration and mango yield under different irrigation treatments. Rev Bras Eng Agríc Ambient 12(2):150-156. https://doi.org/10.1590/S141543662008000200007

Cano LM, Galindo A, Collado GJ, Rodríguez P, Cruz ZN, Legua P, Burló F, Morales D, Carbonell BAA, Hernández F (2018) Influence of deficit irrigation and crop load on the yield and fruit quality in Wonderful and Mollar de Elche pomegranates. J Sci Food Agric 98:3098-3108. https://doi.org/10.1002/jsfa.8810

Carr MKV (2014) The water relations and irrigation requirements of mango (Mangifera indica L.): a review. Exp Agric 50(1):1-23. https://doi.org/10.1017/S0014479713000288

Castro NMT, Reinhardt DH, Ledo SCA (2004) Determination of water potential on mango trees by pressure chamber. Acta Hortic. 645: 425-427. https://doi.org/10.17660/ActaHortic.2004.645.53

Chartzoulakis K, Patakas A, Kofidis G, Bosabalidis A, Nastou A (2002) Water stress affects leaf anatomy, gas exchange, water relations and growth of two avocado cultivars. Sci Hortic 95:39-50. https://doi. org/10.1016/S0304-4238(02)00016-X

Chartzoulakis K, Bertaki M (2015) Sustainable water management in agriculture under climate change. Agric Agric Sci Procedia 4:88-98

Celedón JM, Gil PM, Ferreyra R, Maldonado P, Barrera C (2012) Sensitivity and variability of two plant water stress indicators: exploring criteria for choosing a plant monitoring method for avocado irrigation management. Chilean J Agric Res 72(3):379-387. https:// doi.org/10.4067/S0718-58392012000300012

Corell M, Martín PMJ, Andreu L, Galindo A, López MYE, Moriana A, Girón I, Sánchez BP, Collado J, Hernández GF, Carbonell BAA, Carrillo T, Centeno A, Pérez LD (2019) Evaluation of growers' efforts to improve the sustainability of olive orchards: development of the hydroSOStainable index. Sci Hortic 257(17):108661. https:// doi.org/10.1016/j.scienta.2019.108661

Cotrim CE, Coelho FMA, Coelho EF, Ramos MM, Cecon PM (2011) Regulated deficit irrigation and 'Tommy Atkins' mango orchard productivity under microsprinkling in Brazilian semiarid. Eng Agric 31(6):1052-1063. https://doi.org/10.1590/S010069162011000600003

Cotrim CE, Coelho EF, da Silva JA, dos Santos MR (2017) Regulated deficit irrigation and 'Tommy Atkins' mango crop productivity under drip. Revista Brasileira de Agricultura Irrigada 11(8):2229 2238. https://doi.org/10.7127/rbai.v11n800728

Crane JH, Bally IE, Mosqueda VRV, Tomer E (1997) Crop production. In: The mango: botany, production and uses. CAB International, Wallingford, UK, pp 203-256

Crane JH (2008) Mangifera indica. In: The Encyclopedia of Fruit \& Nuts. CABI, Wallingford, UK, pp 15-20 
Da Silva RVP, De Azevedo PV, De Silva BB, Bassoi LH, AHC T, Soares JM, JAM S (2001) Evaporation estimation in mango orchard using soil water balance. Rev Bras Eng Agríc Ambient 5(3):456-462. https://doi.org/10.1590/S1415-43662001000300015

Da Silva RVP, De Azevedo PV, De Silva BB (2007) Surface energy fluxes and evapotranspiration of a mango orchard grown in a semi-arid environment. Agron J 99:1391-1396. https://doi.org/10. 2134/agronj2006.0232

Da Silva RVP, Campos JHBD, Azevedo PVD (2009) Water-use efficiency and evapotranspiration of mango orchard grown in northeastern region of Brazil. Sci Hortic 120:467-472. https://doi.org/10.1016/j. scienta.2008.12.005

Damour G, Vandame M, Urban L (2009) Long-term drought results in a reversible decline in photosynthetic capacity in mango leaves, not just a decrease in stomatal conductance. Tree Physiol 29:675-684. https://doi.org/10.1093/treephys/tpp011

Darwish WB, El-soufany S (2017) Effect of irrigation regimes on the quality, growth, and productivity of mango. Misr J Agric Eng $34(1): 203-222$

Davenport, TL (2003) Management of flowering in three tropical and subtropical fruit tree species. HortSci 38: 1331-1335. https://doi. org/10.21273/HORTSCI.38.7.1331

Davenport TL (2009) Reproductive physiology. In: The mango - botany, production \& uses, 2nd edn. CABI, Wallingford, UK, pp 97-169

De Azevedo PV, Da Silva BB, Da Silva BPR (2003) Water requirements of irrigated mango orchards in northeast Brazil. Agric Water Manag 58:241-254. https://doi.org/10.1016/S0378-3774(02)00083-5

De Ollas C, Arbona V, Gómez CA (2015) Jasmonic acid interacts with abscisic acid to regulate plant responses to water stress conditions. Plant Signal Behav 10(12):e1078953. https://doi.org/10.1080/ 15592324.2015 .1078953

De Souza PPJO, Rodrigues CJ, De Sousa LAM, Lima TR, Rocha PEJ, Ortega FS (2016) Water requirements estimate for the reproductive period of mango orchards in the northeast of the state of Pará, Brazil. Rev Bras Frutic 38(3):e-311. https://doi.org/10.1590/010029452016311

Diczbalis Y, Kulkarni V, Toohill, B (1993) Mango irrigation and fruit dry matter accumulation. Horticulture Branch Technical Annual Report 1992-1993. Technical Bulletin No. 207, Northern Territory of Australia, Department of Primary Industry and Fisheries, pp 103110

Dhillon R, Rojo F, Upadhyaya SK, Roach J, Coates R, Delwicle M (2019) Prediction of plant water status in almond and walnut trees using a continuous leaf monitoring system. Precision Agric 20:723745. https://doi.org/10.1007/s11119-018-9607-0

Dinesh MR, Ravishankar KV, Nischita P, Sandya BS, Padmakar B, Ganeshan S, Chithiraichelvan R, Sharma TVRS (2015) Exploration, characterization and phylogenetic studies in wild Mangifera indica relatives. Am J Plant Sci 6:2151-2160. https:// doi.org/10.4236/ajps.2015.613217

Dos Santos RM, Martínez AM, Donato RSL (2013) Gas exchanges of Tommy Atkins mango trees under different irrigation treatments. Biosciences J 29:1141-1153

Dos Santos MR, Martinez MA, Donato SLR, Coelho EF (2014a) Fruit yield and root system distribution of 'Tommy Atkins' mango under different irrigation regimes. Rev Bras Eng Agríc Ambient 18(4): 362-369

Dos Santos MR, Martinez MA, Donato SLR, Coelho EF (2014b) 'Tommy Atkins' mango yield and photosynthesis under water deficit in semiarid region of Bahia. Rev Bras Eng Agríc Ambient 18(9): 899-907. 10.1590/1807-1929/agriambi.v18n09p899-907

Dos Santos M, Neves BR, da Silva BL, Donato RSL (2015) Yield, water use efficiency and physiological characteristic of "Tommy Atkins" mango under partial rootzone drying irrigation system. J Water Res Prot 7:1029-1037. https://doi.org/10.4236/jwarp.2015.713084
Dos Santos RM, Donato SLR, Faria LN, Coelho EF, Cotrim JPRF (2016) Irrigation strategies with déficit in 'Tommy Atkins' mango tree. Eng Agr 36(6):1096-1109. https://doi.org/10.1590/1809-4430-eng. agric.v36n6p1096-1109/2016

Durán ZVH, Martínez RA, Aguilar RJ, Franco TD (2003) El cultivo del mango (Mangifera indica L.) en la costa Granadina. ReproDigital Publisher, Granada, Spain

Durán ZVH, Franco TD (2006) Rootstock influence on fruit yield, growth and mineral nutrition of mango (Mangifera indica L. cv. 'Keitt'). Europ J Hortic Sci 71:102-108

Durán ZVH, Rodríguez PCR, Franco TD (2006) Fruit yield, growth and leaf-nutrient status of mangoes grafted on two rootstocks in a marginal growing area (South-East Spain). Fruits 61(3):163-170. https://doi.org/10.1051/fruits:2006014

Durán ZVH, Rodríguez PCR, Franco TD (2011) Impact of sustaineddeficit irrigation on tree growth, mineral nutrition, fruit yield and quality of mango in Spain. Fruits 66:257-268. https://doi.org/10. 1051/fruits/2011038

Durán ZVH, Rodríguez PCR, Francia MJR, Martín PFJ (2013) Land-use changes in s small watershed in the Mediterranean landscape (SE Spain): environmental implications of a shift towards subtropical crops. J Land Use Sci 8:47-58. https://doi.org/10.1080/1747423X. 2011.620992

Durán ZVH, Rodríguez PCR, Gálvez RB, Gutiérrez GS, García-Tejero IF (2019) Water use and fruit yield of mango (Mangifera indica L.) grown in a subtropical Mediterranean climate. Int J Fruit Sci 19(2): 136-150. https://doi.org/10.1080/15538362.2018.1493960

Durán ZVH, Rodríguez PCR, Cárceles RB, Gálvez RB, Gutiérrez GS, Cermeño SP, Cuadros TS, García-Tejero IF (2020) Terraced subtropical farming: sustainable strategies for soil conservation. In: Soil health restoration and management. Springer, Singapore, pp 231278. https://doi.org/10.1007/978-981-13-8570-4_7

Durán ZVH, Franco TD, Cárceles RB, Gálvez RB, Cermeño SP, Cuadros TS, García-Tejero IF (2021) Mango fruit quality improvements in response to water stress: implications for adaptation under environmental constraints. Hort Sci (in press)

Elsheery NI, Cao KF (2008) Gas exchange, chlorophyll fluorescence, and osmotic adjustment in two mango cultivars under drought stress. Acta Physiol Plant 30:769-777. https://doi.org/10.1007/s11738008-0179-x

ESYRCE (2018) Encuesta sobre superficies y rendimientos de cultivos. Ministerio de Agricultura y Pesca y Alimentación. Subsecretaría de Agricultura, Pesca y Alimentación. URL:

Faria LN, Soares AA, Donato SLR, Santos MR, Castro LG (2016) The effects of irrigation management on floral induction of 'Tommy Atkins' mango in Bahia semiarid. Eng Agri 36(3):387-398. https://doi.org/10.1590/1809-4430-Eng.Agric.v36n3p387-398/ 2016

Fernández CA, Arumí JL, Rivera D, Boochs WP (2009) Environmental effects of irrigation in arid and semi-arid regions. Chil J Agric Res 69:27-40. https://doi.org/10.4067/S0718-58392009000500004

Fereres E, Soriano MA (2007) Deficit irrigation for reducing agricultural water use. J Exp Bot 58:147-159

Fukuda S, Spreer W, Yasunaga E, Yuge K, Sardsud V, Müller J (2013) Random forests modelling for the estimation of mango (Mangifera indica L. cv. Chok Anan) fruit yields under different irrigation regimes. Agric Water Manag 116:142-150. https://doi.org/10.1016/j. agwat.2012.07.003

Galindo A, Collado GJ, Griñán I, Corell M, Centeno A, Martín PMJ, Girón IF, Rodríguez P, Cruz ZN, Memmi H, Carbonell BAA, Hernández F, Torrecillas A, Moriana A, López PD (2018) Deficit irrigation and emerging fruit crops as a strategy to save water in Mediterranean semiarid agrosystems. Agric Water Manag 202: 311-324. https://doi.org/10.1016/j.agwat.2017.08.015

Galán SV (2009) Cultivo del mango. Ed. Mundi-Prensa, Madrid Spain 
Galán SV (2015) Current situation and future prospects of worldwide mango production and market. Acta Hortic 1066:69-84. https:// doi.org/10.17660/ActaHortic.2015.1066.7

Galán SV, Lu P (2018) Achieving sustainable cultivation of mangoes. $\mathrm{N}^{\circ}$ 34 de Burleigh Dodds Series in Agricultural Science. Burleigh Dodds Science Publishing Limited, Cambridge, UK

García-Tejero IF, Durán ZVH (2018) Water scarcity and sustainable agriculture in semiarid environment: tools, strategies and challenges for woody crops. Academic Press Elsevier, London, UK, $582 \mathrm{p}$

Gentile C, Di Gregorio E, Di Stefano V, Mannino G, Perrone A, Sortino G, Inglese P, Farina V (2019) Food quality and nutraceutical value of nine cultivars of mango (Mangifera indica L.) fruits grown in Mediterranean subtropical environment. Food Chem 277:471-479. https://doi.org/10.1016/j.foodchem.2018.10.109

Gonçalves A, Silva E, Brito C, Martins S, Pinto L, Dinis LT, Luzio A, Martins GC, Fernandes SA, Ribeiro C, Rodrigues MA, Moutinho PJ, Nunes FM, Correia CM (2020) Olive tree physiology and chemical composition of fruits are modulated by different deficit irrigation strategies. J Sci Food Agric 100:682-694. https://doi.org/10. 1002/jsfa.10064

González A, Lu P, Müller W (2004) Effect of pre-flowering irrigation on leaf photosynthesis, whole-tree water use and fruit yield of mango trees receiving two flowering treatments. Scientia Hortic 102:189211. https://doi.org/10.1016/j.scienta.2003.12.011

Hernández DPM, Aranguren GM, Reig C, Galván FD, Mesejo C, Martínez FA, Galán SV, Agustí M (2011) Phenological growth stages of mango (Mangifera indica $\mathrm{L}$.) according to the $\mathrm{BBCH}$ scale. Sci Hortic 130:536-540. https://doi.org/10.1016/j.scienta. 2011.07.027

Heryani N, Kartiwa B, Apriyana Y, Syahbuddin H (2016) Production and quality enhancement of mango using fan jet sprayer irrigation technique. Indones J Agric Sci 17(2):41-48. https://doi.org/10.21082/ ijas.v17n2.2016.p41-48

Iglesias A, Garrote L (2015) Adaptation strategies for agricultural water management under climate change in Europe. Agric Water Manag 155:113-124. https://doi.org/10.1016/j.agwat.2015.03.014

Isah T (2019) Stress and defence responses in plant secondary metabolites production. Biol Res 52(1):39. https://doi.org/10.1186/s40659-0190246-3

Jabri SAA, Yahyai RA (2017) Plant-soil approach for irrigation scheduling of mango trees in the Sultanate of Oman. Acta Hortic 1150:153158. https://doi.org/10.17660/ActaHortic.2017.1150.22

Jahurul MHA, Zaidul ISM, Ghafoor K, Al-Juhaimi FY, Nyam KL, Norulaini NAN, Sahena F, Mohd OAK (2015) Mango (Mangifera indica $\mathrm{L}$.) by-products and their valuable components: a review. Food Chem 183:173-180. https://doi.org/10.1016/j.foodchem. 2015.03.046

Jovanovic Z, Stikic R (2018) Partial root-zone drying technique: from water saving to the improvement of a fruit quality. Front Sustain Food Syst 1:3. https://doi.org/10.3389/fsufs.2017.00003

Khalifa SM (2018) Effect of different irrigation regimes on yield and fruit quality of two mango cultivars. J Biol Chem Environ Sci 13(3):115132

Kirda C, Moutonnet C, Hera C, Nielsen DR (1999) Crop yield response to deficit irrigation. Springer Publisher, Dordrecht, Netherlands

Kuppelwiesser W (1990). 'Irrigation of mango trees'. Horticulture Branch Technical Annual Report 1990-1991. Technical Bulletin No. 175, Northern Territory of Australia, Department of Primary Industry and Fisheries, pp 82-85

Landsberg J, Waring R, Ryan M (2017) Water relations in tree physiology: where to from here? Tree Physiol 37:18-32. https://doi.org/10. 1093/treephys/tpw102

Larson KD, Schaffer B, Davies FS (1989) Effect of irrigation on leaf water potential, growth and yield of mango trees. Proc Fla State Hort Soc 102:226-228
Léchaudel M, Joas J, Caro Y, Genard M, Jannoyer M (2005) Leaf:fruit ratio and irrigation supply affect seasonal changes in minerals, organic acids and sugars of mango fruit. J Sci Food Agric 85:251-260. https://doi.org/10.1002/jsfa.1968

Léchaudel M, Joas J (2007) An overview of preharvest factors influencing mango fruit growth, quality and postharvest behaviour. Braz J Plant Physiol 19(4):287-298. https://doi.org/10.1590/S167704202007000400004

Levin AG, Peres M, Noy M, Love C, Gal Y, Naor A (2018) The response of field-grown mango (cv. Keitt) trees to regulated deficit irrigation at three phenological stages. Irrig Sci 36:25-35. https://doi.org/10. 1007/s00271-017-0557-5

Lima FJMP (2004) Methodology for water potential measurement on mango using the pressure chamber. Acta Hortic 645: 459-461. https://doi.org/10.17660/ActaHortic.2004.645.59

Lipan L, Cano LM, Corell M, Sendra E, Hernández F, Stan L, Carbonell BAA (2019) Sensory profile and acceptability of HydroSOStainable almonds. Foods 8(2):64. https://doi.org/10. 3390/foods 8020064

Llanes A, Andrade A, Alemano S, Luna V (2018) Metabolomic approach to understand plant adaptations to water and salt stress. In: Metabolites P, Stress RUE (eds) Chapter $\mathrm{N}^{\circ} 6$. Academic Press, Elsevier, Netherlands, pp 133-144

Lu P, Müller WI, Chacko EK (2000) Spatial variations in xylem sap flux density in the trunk of orchard-grown, mature mango trees under changing soil water conditions. Tree Physiol 20:683-692. https:// doi.org/10.1093/treephys/20.10.683

Lu P (2005) Mango water relations and irrigation scheduling. In: Proceedings of International Conference on Mango and Date Palm: Culture and Export. University of Agriculture, Faisalabad, Pakistan, pp 9-19

Luvaha E, Netondo GW, Ouma G (2008) Effect of water deficit on the physiological and morphological characteristics of mango (Mangifera indica) rootstock seedlings. Am J Plant Physiol 5(1): 7-21. https://doi.org/10.3923/ajpp.20081.15

Maatallah S, Guizani M, Hjlaoui H, Boughattas NEH, Lopez LF, Ennajeh M (2015) Improvement of fruit quality by moderate water deficit in three plum cultivars (Prunus salicina L.) cultivated in a semi-arid region. Fruits 70(6):325-332. https://doi.org/10.1051/fruits/ 2015023

Madigu NO, Mathooko FM, Onyango CA, Kahangi EM, Owino WO (2009) Postharvest behaviour and quality characteristics of mango (Mangifera indica L.) fruit grown under water deficit conditions. Acta Hortic 837:305-311. https://doi.org/10.17660/ActaHortic. 2009.837.41

Martínez RMP, Gómez CCM (2016) Key external influences affecting consumer's decision regarding food. Front Psychol 7:1618. https:// doi.org/10.3389/fpsyg.2016.01618

Menzel CM, Le Lagadec MD (2017) Can the productivity of mango orchards be increased by using high-density plantings? Sci Hortic 219:222-263. https://doi.org/10.1016/j.scienta.2016.11.041

Mitra SK (2016) Mango production in the world - present situation and future prospect. Acta Hortic 1111:287-295. https://doi.org/10. 17660/ActaHortic.2016.1111.41

Mohammad FS, Alamoud AI, Mahmoud SH (2015) Water requirements and water use of mango orchards in Jazan Region, Saudi Arabia. J Anim Plant Sci 25(4):1008-1015

Mossad A, Farina V, Lo Bianco R (2020) Fruit yield and quality of 'Valencia' orange trees under long-term partial Rootzone drying. Agron 10:164. https://doi.org/10.3390/agronomy10020164

Mostert PG, Hoffman JE (1997) Water requirements and irrigation of mature mango trees. Acta Hortic 455:331-338. https://doi.org/10. 17660/ActaHortic.1997.455.43

Mukherjee SK, Litz RE (2009) Introduction: botany and importance. In: Mango: botany production and uses. CABI, Wallingford, pp 1-18 
Naor A (2000) Midday stem water potential as a plant water stress indicator for irrigation scheduling in fruit trees. Acta Hortic 537:447454. https://doi.org/10.17660/ActaHortic.2000.537.52

Naor A (2004) The interactions of soil-and stem-water potentials with crop level, fruit size and stomatal conductance of field-grown 'Black Amber' Japanese plum. J Hortic Sci Biotechnol 79: 273-280. https://doi.org/10.1080/14620316.2004.11511760

Nadler A, Raveh E, Yermiyahu U, Green S (2006) Stress induced water content variations in mango stem by time domain reflectometry. Soil Sci Soc Am J 70:510-520. https://doi.org/10.2136/sssaj2005.0127

Nettey SNA, Agodzo SK, Fialor SC, Marx W, Asare DK, Amoatey HM, Amenorpe G, Djanma S (2017) The impact of irrigation on the reproductive growth parameters of mango in a coastal savannah agroecological zone of Ghana. Afr J App Res 3(1):106-120

Noguera AL, Lipan L, Vázquez AL, Barber X, Pérez LD, Carbonell BAA (2016) Opinion of Spanish consumers on hydrosustainable pistachios. J Food Sci 81:2559-2565. https://doi.org/10.1111/17503841.13501

Nora L, Dalmazo GO, Nora FR, Rombaldi CV (2012) Controlled water stress to improve fruit and vegetable postharvest quality. In: Water Stress. IntechOpen, Rijeka, Croatia, pp 59-72. https://doi.org/10. $5772 / 30182$

Normand F, Lauri PE, Legave JM (2015) Climate change and its probable effects on mango production and cultivation. Acta Hortic 1075:2131. https://doi.org/10.17660/ActaHortic.2015.1075.1

Núñez ER, Davenport TL (1994) Flowering of mango trees in containers as influenced by seasonal temperature and water stress. Sci Hortic 58:57-66. https://doi.org/10.1016/0304-4238(94)90127-9

OPM (2020) Observatorio de Precios y Mercados 2020. Consejería de Agricultura, Ganadería, Pesca y Desarrollo Rural, Junta de Andalucía. URL: https://www.juntadeandalucia.es/ agriculturaypesca/observatorio/servlet/FrontController?action= Static\&subsector $=34 \&$ url=subsector.jsp.

Pavel EW, Vanassche FMG, Grossman YL (2003) Optimization of irrigation management in mango trees by determination of water and carbon demands to improve water use efficiency and fruit quality. Final report to the Water Research Commission, WRC Report No.: 1136/1/03. Pretoria, South Africa. $106 \mathrm{p}$

Pavel EW, Villiers AJD (2004) Responses of mango trees to reduced irrigation regimes. Acta Hortic 646:63-68. https://doi.org/10. 17660/ActaHortic.2004.646.7

Pérez SF, Mirás AJM, Alcobendas R, Alarcón JJ, Mounzer O, Nicolás E (2016) Effects of regulated deficit irrigation on physiology, yield and fruit quality in apricot trees under Mediterranean conditions. Span J Agric Res 14(4):e1205. https://doi.org/10.5424/sjar/ 2016144-9943

Pongsomboon W (1991) Effects of temperature and water stress on tree growth, flowering, fruit growth and retention of mango (Mangifera indica L.). PhD. Thesis, Kasetsart University, Bangkok, Thailand. $418 \mathrm{p}$

Ramos RRD, Melo Júnior JCF (2019) Mapping of the current land use in part of the Irrigated Perimeter Nilo Coelho, Petrolina-PE, Brazil. Comunicata Scientiae 10(1):89-97. https://doi.org/10.14295/cs. v10i1.2739

Romero P, García GJ, Fernández FJI, Gil MR, del Amor SF, Martínez CA (2016) Improving berry and wine quality attributes and vineyard economic efficiency by long-term deficit irrigation practices under semiarid conditions. Sci Hortic 203:69-85. https://doi.org/10.1016/ j.scienta.2016.03.013

Rosalie R, Joas J, Deytieux-Belleau C, Vulcain E, Payet B, Dufossé L, Léchaudel M (2015) Antioxidant and enzymatic responses to oxidative stress induced by pre-harvest water supply reduction and ripening on mango (Mangifera indica L. cv. 'Cogshall') in relation to carotenoid content. J Plant Physiol 184:68-78. https://doi.org/10. 1016/j.jplph.2015.05.019
Sánchez RL, Corell M, Hernández F, Sendra E, Moriana A, Carbonell BAA (2019) Effect of Spanish-style processing on the quality attributes of HydroSOStainable green olives. J Sci Food Agric 99:1804 1811. https://doi.org/10.1002/jsfa.9373

Satienperakul K, Manochai P, Ongprasert S, Spreer W, Müller J (2009) Economic evaluation of different irrigation regimes in mango production in northern Thailand. Acta Hortic 831:293-300. https://doi. org/10.17660/ActaHortic.2009.831.34

Saxena P, Singh VK, Rajan S (2017) Assessment of water relation traits during different phenological stages in mango (Mangifera indica L.). Indian J Hortic 74(4):479-485. https://doi.org/10.5958/09740112.2017.00094.9

Schaffer B, Whiley AW, Crane JH (1994) Mango. In: environmental physiology of fruit crops, Vol. II: sub-tropical and tropical crops, Florida: CRC Press, pp 165-197

Schaffer B, Urban L, Lu P, Whiley AW (2009) Ecophysiology. In: The mango - botany, production and uses, 2nd edn. CABI, Wallingford, UK, pp 170-209

Schulze K, Spreer W, Keil A, Ongprasert S, Müller J (2013) Mango (Mangifera indica L. cv. Nam Dokmai) production in Northern Thailand - costs and returns under extreme weather conditions and different irrigation treatments. Agric Water Manag 126:46-55. https://doi.org/10.1016/j.agwat.2013.04.010

Sepaskhah AR, Ahmadi SH (2010) A review on partial root-zone drying irrigation. Int J Plant Prod 4:241-258

Shah NH, Arshad I, Khan ZA (2018) Effect of different levels of water stress on the growth and yield of mango (Mangifera indica L.) by using drip irrigation technology. Int J Altern Fuels Energy 2(2):34-38

Shyam R, Prakash S, Prasad J (2019) Conservation practice, irrigation and fertilizer dose influence yield and quality of mango cv. Amrapali under high density orchard in Kosi zone of Bihar. Curr J Appl Sci Technol 37(6):1-6. https://doi.org/10.9734/CJAST/2019/v37i630337

Simmons SL, Hofman PJ, Whiley AW, Hetherington SE (1998) Effects of leaf to fruit ratios on fruit growth, mineral concentration and quality of mango (Mangifera indica L cv Kensington Pride). J Hort Sci Biotechnol 73:367-374. https://doi.org/10.1080/ 14620316.1998.11510987

Souza AJM, Leonel S, Modesto JH, Ferraz RA, Silva SM, Bolfarini BAC (2018) Performance of mango cultivars under subtropical conditions in the state of São Paulo. Bioscience J 34:1-11. https://doi.org/10. 14393/BJ-v34n1a2018-37163

Spreer W, Nagle M, Neidhart S, Carle R, Ongprasert S, Müller J (2007) Effect of regulated deficit irrigation and partial rootzone drying on the quality of mango fruits (Mangifera indica L., cv. 'Chok Anan'). Agric Water Manag 88:173-180. https://doi.org/10.1016/j.agwat. 2006.10.012

Spreer W, Müller J, Hegele M, Ongprasert S (2009a) Effect of deficit irrigation on fruit growth and yield of mango (Mangifera indica L.) in northern Thailand. Acta Hortic 820:357-364. https://doi.org/10. 17660/ActaHortic.2009.820.41

Spreer W, Ongprasert S, Hegele M, Wunsche JN, Müller J (2009b) Yield and fruit development in mango (Mangifera indica L. cv. Chok Anan) under different irrigation regimes. Agric Water Manag 96: 574-584. https://doi.org/10.1016/j.agwat.2008.09.020

Spreer W, Schulze K, Ongprasert S, Alongkorn WW, Müller J (2013) Mango and longan production in Northern Thailand: the role of water saving irrigation and water stress monitoring. In: Sustainable land use and rural development in Southeast Asia: innovations and policies for mountainous areas. Springer Environmental Science and Engineering. New York, USA, pp 215-228

Srikasetsarakul U, Sringarm K, Sruamsiri P, Spreer W, Schulze K, Müller J, Ongprasert S (2011) Effects of partial rootzone drying irrigation on proline content and yield of mango in a commercial orchard. In: Global Conference on 'Augmenting Production and Utilization of Mango: Biotic and Abiotic Stresses', Lucknow (India). ISHS, ICAR, pp 21-24 
Subbaiah KV, Reddy NN, Reddy MLN, Dorajeerao AVD, Reddy AGK (2017) Effect of different irrigation levels on yield and physiological-biochemical characteristics of mango cv. Banganpalli. Int J Pure App Bioscience 5(6):177-182. https://doi.org/10.18782/2320-7051. 5840

Tahir FM, Ibrahim M, Kamran H (2003) Effect of drought stress on vegetative and reproductive growth behavior of mango (Mangifera indica L.). Asian J Plant Sci 2(1):116-118. https://doi.org/10.3923/ ajps.2003.116.118

Testa R, Tudisca S, Schifani G, Di Trapani AM, Migliore G (2018) Tropical fruits as an opportunity for sustainable development in rural areas: the case of mango in small-sized Sicilian farms. Sustainability 10(5):1436. https://doi.org/10.3390/su10051436

Teixeira AHC, Bastiaanssen WGM, Moura MSB, Soares JM, Ahmad MD, Bos MG (2008) Energy and water balance measurements for water productivity analysis in irrigated mango trees, Northeast Brazil. Agric For Meteorol 148:1524-1537. https://doi.org/10. 1016/j.agrformet.2008.05.004

Tharanathan RN, Yashoda HM, Prabha TN (2006) Mango (Mangifera indica L.), "the king of fruits"-an overview. Food Rev Int 22(2):95123. https://doi.org/10.1080/87559120600574493
Turner NC (1979) Drought resistance and adaptation to water deficits in crop plants. In: Stress physiology in crop plants. Wiley-Interscience, New York, pp 343-372

Wang Y, Liu L, Wang Y, Tao H, Fan J, Zhao Z, Guo Y (2019) Effects of soil water stress on fruit yield, quality and their relationship with sugar metabolism in 'Gala' apple. Sci Hortic 258:108753. https:// doi.org/10.1016/j.scienta.2019.108753

Wei J, Liu G, Liu D, Chen Y (2017) Influence of irrigation during the growth stage on yield and quality in mango (Mangifera indica $\mathrm{L}$ ). PLoS One 12(4):e0174498. https://doi.org/10.1371/journal.pone. 0174498

Williamson J, Crane J (2010) Best management practices for temperate and tropical/subtropical fruit crops in Florida: current practices and future challenges. HortTech 20:111-119. https://doi.org/10.21273/ HORTTECH.20.1.111

Zaharah SS, Razi IM (2009) Growth, stomata aperture, biochemical changes and branch anatomy in mango (Mangifera indica) $c v$. Chokanan in response to root restriction and water stress. Sci Hortic 1:58-67. https://doi.org/10.1016/j.scienta.2009.07.022

Publisher's note Springer Nature remains neutral with regard to jurisdictional claims in published maps and institutional affiliations. 